\title{
The Expected Inflation Channel of Government Spending in the Postwar U.S.
}

\author{
Bill Dupor \\ and \\ Rong Li
}

\author{
Working Paper 2013-026B \\ https://doi.org/10.20955/wp.2013.026
}

October 2014

\author{
FEDERAL RESERVE BANK OF ST. LOUIS \\ Research Division \\ P.O. Box 442 \\ St. Louis, MO 63166
}

The views expressed are those of the individual authors and do not necessarily reflect official positions of the Federal Reserve Bank of St. Louis, the Federal Reserve System, or the Board of Governors.

Federal Reserve Bank of St. Louis Working Papers are preliminary materials circulated to stimulate discussion and critical comment. References in publications to Federal Reserve Bank of St. Louis Working Papers (other than an acknowledgment that the writer has had access to unpublished material) should be cleared with the author or authors. 


\title{
The Expected Inflation Channel of Government Spending in the Postwar U.S.*
}

\author{
Bill Dupor ${ }^{\dagger}$ and Rong $\operatorname{Li}^{\ddagger}$
}

May 12, 2014

\begin{abstract}
There exist sticky price models in which the output response to a government spending change can be large if the central bank is nonresponsive to inflation. According to this "expected inflation channel," government spending drives up expected inflation, which in turn, reduces the real interest rate and leads to an increase in private consumption. This paper examines whether the channel was important in the post-WWII U.S., with particular attention to the 2009 Recovery Act period. First, we show that a model calibrated to have a large output multiplier requires a large response of expected inflation to a government spending shock. Next, we show that this large response is inconsistent with structural vector autoregression evidence from the Federal Reserve's passive policy period (1959-1979). Then, we study expected inflation measures during the Recovery Act period in conjunction with a panel of professional forecaster surveys, a cross-country comparison of bond yields and fiscal policy news announcements. We show that the expected inflation response was too small to engender a large output multiplier.
\end{abstract}

Keywords: monetary policy, fiscal policy, output multipliers, 2009 Recovery Act.

JEL Codes: E52, E62.

\footnotetext{
${ }^{*}$ The authors thank Rüdiger Bachmann, Charles Carlstrom, John Cochrane, Gauti Eggertsson, Chris Erceg, Paul Evans, Patrick Kehoe, Eric Leeper, Jesper Linde, Matthias Paustian as well as audience members at the EABCN-INET Conference on Macroeconomic Stabilization and Economic Recovery after the Financial Crisis, the Federal Reserve Banks of Richmond and St. Louis, the Midwest Macroeconomics Conference as well as the NBER Economic Fluctuations and Growth meeting. The authors also thank Peter McCrory for helpful research assistance. A repository containing government documents, data sources, a bibliography and other relevant information pertaining to the Recovery Act is available at billdupor.weebly.com. The analysis set forth does not reflect the views of the Federal Reserve Bank of St. Louis or the Federal Reserve System. First draft: April 2013.

${ }^{\dagger}$ Federal Reserve Bank of St. Louis, william.d.dupor@stls.frb.org, billdupor@gmail.com.

${ }^{\ddagger}$ The Ohio State University and Renmin University, li.1086@osu.edu.
} 


\section{Introduction}

In February 2009, the U.S. government began mounting a massive fiscal stimulus program: the American Recovery and Reinvestment Act, also known as the Recovery Act. The Congressional Budget Office's most recent assessment is that the Act's budget impact will total $\$ 830$ billion, hundreds of billions of which was government spending. The remainder consisted of tax cuts, tax incentives and entitlements. While some analysts have argued that the Act had a strong positive impact on the macroeconomy (e.g. Blinder and Zandi (2010) and Council of Economic Advisers (various quarterly reports)), the workhorse neoclassical growth model implies that stimulative government-spending policy has a muted effect on total economic activity. In that model, increased government spending reduces households' after-tax lifetime income, which leads them to reduce consumption. In the language of introductory macro textbooks, government spending "crowds out" consumption and the "output multiplier" is less than 1.

A number of researchers have posited that there exists an expected inflation channel for government spending, in which consumption rises rather than falls. ${ }^{1}$ According to this channel, government spending drives up the current and expected future real wage. If a business may be unable to change its price for some duration, the shift up in its expected real wage path leads the business to increase its price today. This shift will generate expected inflation which, in turn, reduces the expected real rate; such a reduction leads households to shift consumption toward the present. This effect is particularly strong when a central bank does not react to inflation by tightening its monetary policy. One reason that a central bank might be unresponsive is that a zero lower bound on the nominal rate may be binding.

Some have contended that the channel was important during particular historical episodes. Eggertsson (2012) examines this channel in the context of the New Deal and concludes that it helped end the Great Depression. Christiano, Eichenbaum and Rebelo (2011) examine the mechanism during the 2009 Recovery Act period and conclude that it had an output multiplier as high as 2.3.

In light of the limitations on monetary policy because of the zero lower bound (ZLB), the Recovery Act may seem an ideal catalyst for the expected inflation channel. First, it was a massive program. For example, highway and bridge construction and improvement funded by the Act was $\$ 28$ billion; this equaled $76 \%$ of 2008 federal-aid highway dollars ( $\$ 36.9$ billion). Without the Act, wages in this part of the construction industry might have been substantially lower, thus exerting downward pressure on inflation. As a second example, the Act allocated over $\$ 50$ billion to pay public school teachers and other government workers. Without this component, it is likely that fewer government employees would have been added to payrolls, fewer would have received pay raises, some layoffs would have occurred and government furloughs would have been more common. This could have conceivably driven down wages in the government sector, putting downward pressure

\footnotetext{
${ }^{1}$ See for example Christiano (2004), Christiano, Eichenbaum and Rebelo (2011), Eggertsson (2004), Erceg and Linde (2010) and Woodford (2011). The phrase we use to describe this channel is of our making.
} 
on inflation.

The Act also introduced inefficient "wedges" into the economy, which act like negative "supply" shocks, and might have put upward pressure on inflation. For example, the Davis-Bacon requirements in the Act required private contractors on many of the Act's projects to pay "prevailing wages," which are often tied to union-negotiated pay scales. Through this and other wedges, the Act may have helped prevent downward pressure on the market wage and thus inflation.

This paper answers a narrow question: did the expected inflation channel engender a large output multiplier during periods of monetary accommodation in the post-WWII U.S.? ${ }^{2}$

We execute two distinct strategies to measure the magnitude of the expected inflation channel. Neither strategy finds a quantitatively important effect. Our first strategy stems from an observation about the New Keynesian paradigm: large output multipliers arise through the nonresponsiveness of the central bank's interest rate; the zero-lower bound is simply one basis for non-responsiveness. We observe that monetary policy was much less responsive to inflation in the 20 years preceding 1980 than in the twenty years that followed. As such, the expected inflation channel hypothesis implies that inflation should respond more to government spending shocks in the earlier, relative to the later, period.

Using a sticky price model (as typically calibrated), we show how the multiplier is much larger under a passive (relative to an active) monetary policy. Then, we examine the data from the two periods, specifically 1959-79 and 1981-2002. We identify impulse responses to government spending shocks using stock return data on U.S. military contractors, following Fisher and Peters (2010). During the passive policy period, there is a -8 bp one-year inflation response to a Recovery Act sized spending shock. The corresponding response during the active period is -176 bp. Neither of the two periods show support for the expected inflation channel: inflation falls rather than rises in response to positive spending shocks. Moreover, we find a statistically insignificant response of consumption to government spending at all horizons, which is also consistent with a weak expected inflation channel.

For the second strategy, we begin by calibrating a model which has a transiently non-responsive monetary policy (e.g., a ZLB constraint is temporarily binding) such that it generates a large output multiplier. We then calculate and record the model's expected inflation response to a Recovery Act sized spending shock. In our baseline calibration, the implied one-year expected inflation response is $5.23 \%$, which we view as very large.

Next we turn to the data on actual and expected inflation during the Recovery Act episode. Actual inflation changed very little during the entire episode, both pre- and post-passage of the Act. The U.S. had not entered into a deflationary spiral before the passage (as well as the preceding months during which news of a federal spending program developed), nor did it experience a

\footnotetext{
${ }^{2}$ Broader questions, such as whether the Act stimulated economic activity through some other mechanism or whether the expected inflation channel was quantitatively important during other historical episodes, are touched on only briefly in this paper.
} 
noticeable inflation increase after its passage. Since actual inflation changed very little, one would expect the mechanism to be manifested in expected inflation.

Here is what the data tell us. From before to after enactment, the median forecast of expected inflation from the Survey of Professional Forecasters (hereafter SPF) showed a small increase - an order of magnitude smaller than implied by the calibrated sticky price model. Moreover, across the panel of individual surveyed forecasters, there was no systematic increase in inflation expectations by a forecaster and that forecaster's measured increase in expected government spending growth. That is, forecasters predicting a large stimulus were no more likely to revise their inflation projections substantially upward.

We also measure inflation expectation from bond markets. "Break-even inflation" in a country is calculated as the spread between nominal and indexed yields on that country's government bonds. During the news/passage of the Act, break-even inflation in the U.S. and U.K. tracked each other closely. This is telling because the U.K. did not enact, nor did it ever approach enacting, a fiscal stimulus program during this time frame. In addition, we show that U.S. break-even inflation moved very little on days of important fiscal policy news during the development of and legislating on the Recovery Act.

The outline of the paper follows. Section 2 uses the behavior of pre- and post-1980 monetary policy to assess the importance of the expected inflation channel. Section 3 builds a sticky price model and calculates the inflation and output responses to a Recovery Act size spending policy under several alternative scenarios and then catalogs evidence on expected inflation pre- and postpassage of the Recovery Act. Section 4 discusses existing research and Section 5 concludes.

\section{The Passive Policy Era: Theory and Evidence}

\subsection{A Sticky Price Model with Passive Policy}

Consider the following log-linearized sticky price model:

$$
\begin{gathered}
i_{t}-E_{t}\left(\pi_{t+1}\right)=\sigma\left[E\left(c_{t+1}\right)-c_{t}\right] \\
\pi_{t}=\beta E_{t}\left(\pi_{t+1}\right)+\kappa\left(\sigma c_{t}+\nu y_{t}\right) \\
y_{t}=(1-s) c_{t}+s g_{t}
\end{gathered}
$$

where $c_{t}, y_{t}, \pi_{t}, i_{t}$ and $g_{t}$ are, respectively, the log deviations of consumption, output, inflation, the nominal interest rate and government spending from their corresponding steady-state values. ${ }^{3}$ For simplicity, assume steady-state net inflation equals zero. Assume further that government spending is financed by lump-sum taxes.

\footnotetext{
${ }^{3}$ Here $\sigma, v$ and $\kappa$ are non-negative and $\beta$ and $s$ lie inside the unit interval. The model set up and notation follow Carlstrom, Fuerst and Paustian (2012).
} 
Figure 1: A characterization of alternative interest rule rules.

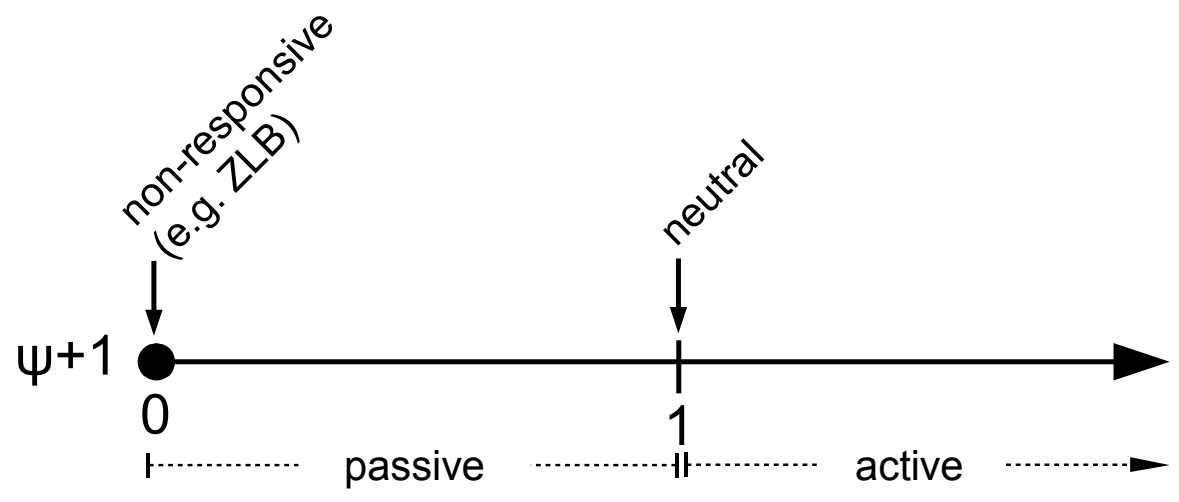

Notes: "ZLB" abbreviates zero lower bound. The interest rate rule in the above equation is $i_{t}=$ $(\psi+1) E_{t}\left(\pi_{t+1}\right)$.

Substituting $y_{t}$ out of (2.2) using (2.3), we have

$$
\pi_{t}=\beta E_{t}\left(\pi_{t+1}\right)+\chi c_{t}+\omega g_{t}
$$

where $\chi=\kappa(\sigma+v(1-s))$ and $\omega=\kappa s v$.

Large output multipliers can arise through the weak response of the central bank's interest rate to inflation. Boivin and Giannoni (2006) and Clarida, Gali and Gertler (2000), among others, provide evidence that monetary policy was passive (i.e. partially non-responsive) during part of the post-WWII period. See Figure 1. This episode will help us evaluate the expected inflation channel because we have decades of data under which U.S. monetary policy was passive (1959-79), as well as decades under which policy was active (1981-2002). Moreover, existing methods for identifying exogenous shocks to government spending will allow us to compute the response of inflation to spending shocks. With the identified impulse responses, we will quantify the expected inflation channel.

Returning to the model, imagine monetary and fiscal policy are set according to

$$
i_{t}=(\psi+1) E_{t}\left(\pi_{t+1}\right) \text { and } g_{t}=\rho g_{t-1}+\varepsilon_{t}
$$

where $\varepsilon_{t}$ is mean zero white noise. Policy is active when $\psi>0$ and passive when $\psi<0$. Here, we following existing research and model these policies such that agents behave as if the passive policy will remain in place forever.

Thus, we have 3 endogenous variables $\left\{c_{t}, i_{t}, \pi_{t}\right\}$ in 3 equations, (2.1), (2.4) and (2.5). Using the method of undetermined coefficients, we can solve for the model's rational expectations equilibria 
close to its steady state. For an active policy, the equilibrium is typically unique. ${ }^{4}$ Under passive policies, the equilibrium is not unique. For this case, we follow Boivin and Giannoni (2006) and analyze the "minimum state variable" or bubble-free equilibrium.

For both active and passive rules, inflation and output in equilibrium are given by

$$
\begin{gathered}
\pi_{t}=\alpha g_{t}=\frac{\omega(1-\rho)}{\beta\left(\rho^{2}+\theta \rho+\beta^{-1}\right)} g_{t} \\
c_{t}=\gamma g_{t}=\chi^{-1}[(1-\beta \rho) \alpha-\omega] g_{t}
\end{gathered}
$$

where $\theta=\beta^{-1}\left(\sigma^{-1} \chi \psi-\beta-1\right)$.

The response coefficients $\alpha$ and $\gamma$ change with the responsiveness of monetary policy as one would predict. Letting $\alpha=\alpha(\psi)$, one can show first that $\alpha(0)=\omega /(1-\beta \rho)>0$. Thus, for a policy that raises the nominal rate one for one with expected inflation (often called a neutral policy), a government spending shock will increase inflation. Also, within a range of $\psi$ that contains zero, $(\hat{\psi}, \bar{\psi})$, one can show that $\alpha(\psi)>0$ and $\alpha^{\prime}(\psi)<0$.

Thus, within this range, (i) government spending shocks are inflationary for both active and passive policies, and (ii) a more passive policy results in a greater inflation response. Panel (a) of Figure 2 represents these features diagrammatically.

Next, panel (b) of Figure 2 plots how the consumption response depends on monetary policy, that is $\gamma=\gamma(\psi)$. The diagram shows that $\gamma(0)=0$, and $\gamma^{\prime}(\psi)<0$ within a neighborhood of $\psi=0$. Thus, consumption does not respond to government spending shocks if monetary policy is neutral; active policy implies consumption decreases in response to a positive government spending shock; passive policy implies consumption increases in response to a positive government spending shock. Furthermore, within some range, the consumption response is monotonically decreasing in $\psi$.

Next, we proceed by quantifying the effect of varying the degree of accommodation. This requires setting numerical values for the parameters. We set $\psi_{A}=0.5$ and $\psi_{P}=-0.5$ for the active and passive policies, respectively. We set $\rho=0.75$. Next, the magnitude of the $\varepsilon_{t}$ shock is chosen so that the resulting cumulative increase in $g$ equals $10 \%$ of one year's level of steady-state government spending. The next four parameters are set as:

$$
\beta=0.995, \quad s=0.2, \quad \sigma=1, \quad v=4
$$

We report results for several different values of $\kappa$, the parameter dictating the response of inflation to marginal cost.

The first choice of $\kappa$ is 0.02 . The calculations of $\alpha$ and $\gamma$ appear in Table 1. For the passive rule, the cumulative output multiplier equals 1.75; for the active rule, the corresponding value is

\footnotetext{
${ }^{4}$ For very large (and typically argued unrealistic) values of $\psi$, active policies can result in indeterminacy. We avoid this region of the parameter space in the numerical exercises that follow.
} 
Figure 2: Equilibrium impact responses of inflation and consumption to a government spending shock under active $(\psi>0)$ and passive $(\psi<0)$ rules

$\alpha$,

(a)

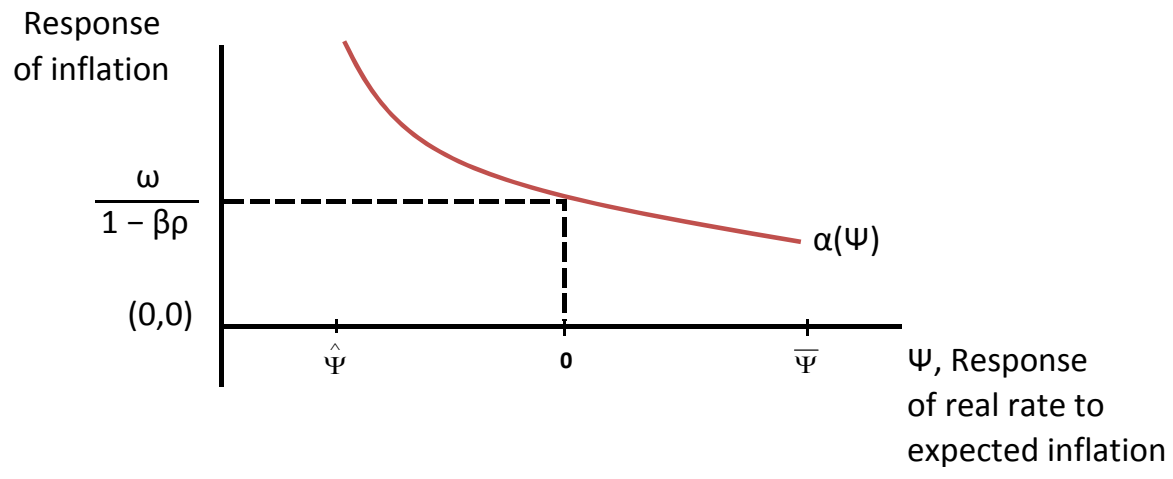

(b)

$\gamma$,

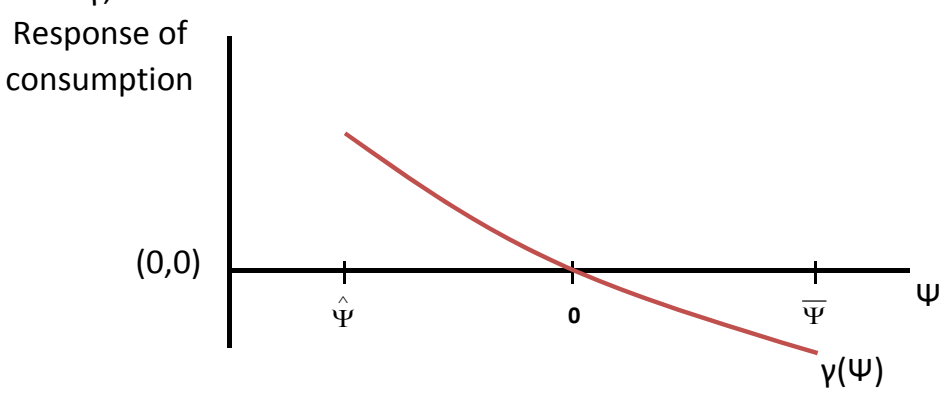


Table 1: Responses to a government spending shock under passive and active interest rate policies.

\begin{tabular}{|c|c|c|}
\hline $\begin{array}{l}\text { Type of } \\
\text { monetary policy }\end{array}$ & $\begin{array}{l}\text { Expected one-year } \\
\text { price level response }\end{array}$ & $\begin{array}{l}\text { Output multiplier } \\
\text { (cumulative) }\end{array}$ \\
\hline \multicolumn{3}{|c|}{$\mathrm{K}=0.02$} \\
\hline Passive & $3.42 \%$ & 1.75 \\
\hline Active & $1.15 \%$ & 0.75 \\
\hline \multicolumn{3}{|c|}{$K=0.01$} \\
\hline Passive & $1.15 \%$ & 1.25 \\
\hline Active & $0.69 \%$ & 0.85 \\
\hline \multicolumn{3}{|c|}{$K=0.04$} \\
\hline Passive & $500 \%$ & 110 \\
\hline Active & $1.73 \%$ & 0.62 \\
\hline
\end{tabular}

Notes: The government spending process is $\mathrm{AR}(1)$ with coefficient $0.75 . \kappa$ is the coefficient on marginal cost in the inflation Euler equation. The price level responses are with respect to a shock with expected, cumulative magnitude equal to $10 \%$ of one-year's steady-state government spending.

0.75. The fall in the real interest rate under the passive rule leads households to increase current consumption.

The inflation response is larger under the passive rule, relative to the active rule. In response to the spending shock, the 1-year inflation rate is $3.42 \%$ under the passive rule in contrast to $1.15 \%$ under the active rule.

Next, we ask what value the output multiplier would take in the passive-policy model economy where, all other things equal, the spending shock caused a more moderate increase in inflation. The next entries in Table 1 show that, when $\kappa=0.01$, the inflation response is 0.46 percentage points larger (i.e. 1.15\%-0.69\%) under the passive rule. The corresponding difference in output multipliers is 0.40 (that is, 1.25-0.85). Thus, the expected inflation channel is operative when policy is passive, however; quantitatively it accounts for only a small change in the multiplier when the inflation response is set at a moderate level.

As a final illustration, we report the same statistics, except we set $\kappa=0.04$. Under the passive rule, the multiplier becomes extremely large: one unit of additional government spending results in 110 additional units of output. This extremely large output multiplier is supported by an extremely large inflation response. For this calibration, the one-year inflation rate $500 \%$ in response to the Recovery Act sized spending shock.

\subsection{Evidence from the Passive Policy Era}

The numbers in Table 1 give predictions for output multipliers and inflation responses under passive and active policies. Next, we compare these numbers with those from U.S. data using a suitably 
identified estimation strategy.

We wish to estimate the structural responses to government spending shocks without imposing too many restrictions from economic theory. We follow Fisher and Peters (2010), who identify these shocks using the total excess returns of a portfolio of corporations that are major U.S. defense contractors.

The excess return of defense contractors satisfies the two criteria for a sound instrument. First, it is correlated with our endogenous variable because: (i) defense spending is a substantial component of overall government spending, and (ii) defense contractors tend to earn above market returns when there are positive innovations to government spending. Note that the instrument is plausibly exogenous with respect to the error term because defense spending is driven mainly by international geopolitical factors rather than the U.S. business cycle. Moreover, because stock prices are forward-looking, the Fisher and Peters (2010) instrument is capable of capturing the news aspect of government spending shocks unlike a number of alternative approaches, e.g. some based on time- 0 recursive identification.

Our construction of the defense contractors' excess returns follows Fisher and Peters (2010) almost exactly ${ }^{5}$ as such, we describe the construction briefly here and direct interested readers to their paper for greater detail.

Since 1956, the U.S. Department of Defense has published annual reports of the 100 companies that are top military contractors by dollar volume. These reports, with a few modifications used by Fisher and Peters (2010), provide the data to construct the portfolio of large military suppliers. First, companies are removed from the list if their primary source of revenue is not defense (e.g. AT\&T). Then, companies are removed if they were not one of the top three contractors within at least one month over the entire period. The remaining companies are listed in Table 1 of Fisher and Peters (2010). The portfolio of defense contractors is then the market-capitalization-weighted sum of the remaining firms.

Our benchmark specification includes the following variables: accumulated excess returns for key defense firms, real total government purchases, real personal consumption spending, the core CPI level, a linear trend and a constant.

All of the variables are included in natural log form. Government purchases consist of deseasonalized consumption and investment of federal, local and state governments. When an original series is measured quarterly, we linearly interpolate between each pair of quarterly observations to construct monthly values.

The source for consumption is the monthly Personal Consumption Expenditure survey. We deflate by the CPI to obtain a real variable. Our inflation measure in each month is computed as the annualized three-month growth rate of the core CPI; in addition, we use the 3-month rather than the 1-month growth in the price index with the aim of smoothing out very transient movements

\footnotetext{
${ }^{5}$ They compute quarterly returns, whereas we compute monthly returns.
} 
Table 2: Estimate of the one-year inflation response (APR) to a Recovery Act sized government spending shock and the consumption multiplier, from structural vector autoregression, for alternative sample periods

\begin{tabular}{lcc} 
Sample period & One-year inflation response & Consumption multiplier \\
\hline Passive & -0.08 & 0.35 \\
& $(-1.39,1.65)$ & $(-1.27,1.71)$ \\
Active & -1.76 & 1.63 \\
& $(-8.86,5.24)$ & $(-4.44,5.53)$ \\
\hline \hline
\end{tabular}

Notes: Median estimates from 500 bootstrap simulations. Corresponding $90 \%$ confidence intervals appear in parentheses. The consumption multiplier is the cumulative response of consumption divided by the cumulative response of government spending, each summed over the first 3 years following the shock.

in inflation.

Our passive (monetary policy) period covers 1959:1-1979:12; our active (monetary policy) period consists of 1981:10-2002:6. The first period corresponds to a time when policy was overly accommodative of inflation, as described in Taylor (1999). Our dividing point between passive and active periods corresponds to the ascendancy of Paul Volcker as chairman of the Federal Reserve. We chose the end date for the active period based on Taylor (2007). Taylor (2007) writes that between early 2002 and 2005, "no greater or more persistent deviation of actual Fed policy [from the Taylor rule] had been seen since the turbulent days of the 1970s" (pg. 2).

In our benchmark specification, we use 9 lags, as chosen by the Akaike information criterion.

Panels (a) and (b) of Figure 3 plot the impulse responses of government spending to an innovation to accumulated excess returns for each period. The size of the shock fed into the system is selected so that the government spending increase is comparable to the Recovery Act. In particular, for each sample the cumulative spending increase during the first three years equals $10 \%$ of one year of typical government spending.

Panel (a) shows that the shock generates a hump-shaped response of spending during the passive policy period. Initially, there is almost no effect on spending. It reaches a plateau at month 13 and remains near the plateau for another 18 months. Spending then monotonically returns to roughly its steady state by the end of year 4 . The dashed lines envelope the pointwise $68 \%$ confidence interval.

The impulse response in Figure 3(a) is encouraging for two reasons. First, the responses are very similar, apart from a different scaling of the shock, to the corresponding figure in Fisher and Peters (2010), despite the fact that: (i) they use a longer sample (1957-2007), (ii) use a quarterly frequency, and (iii) select somewhat different variables into their vector autoregression. Second, the impulse response also has the qualitative shape of the spending path authorized by the Recovery 
Figure 3: Impulse responses to a shock to the accumulated excess returns on a portfolio of major U.S. military contractors from a structural vector autoregression, for alterative sample periods, in percentage deviation terms

(a) Passive period

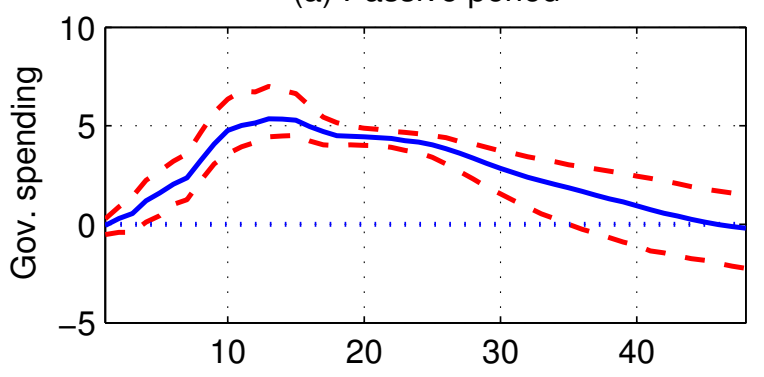

(c) Passive period

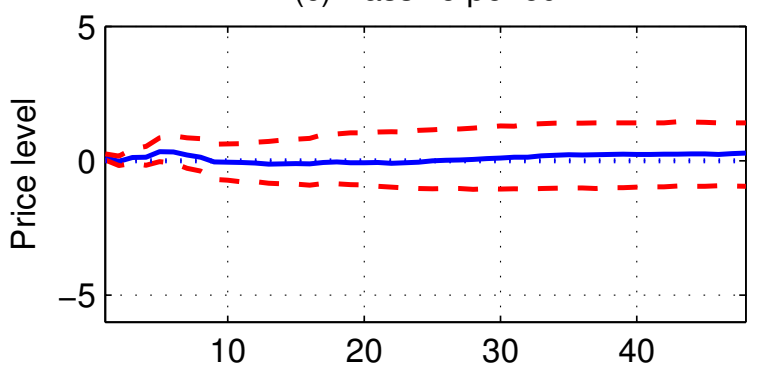

(e) Passive period

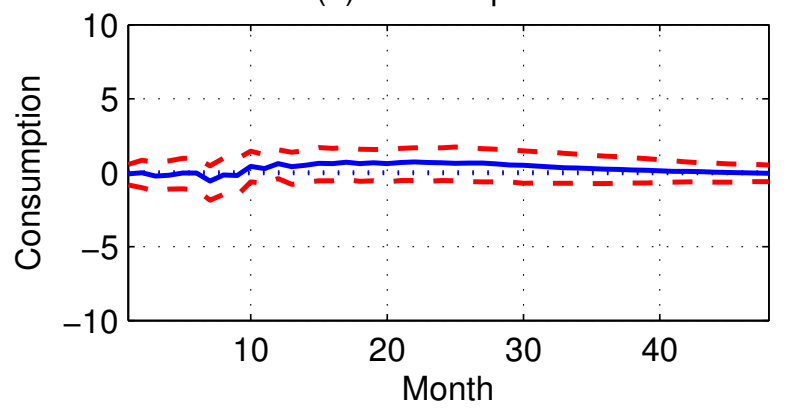

(b) Active period

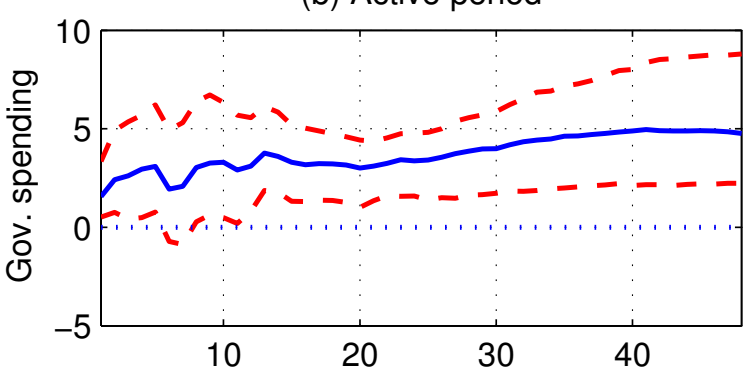

(d) Active period

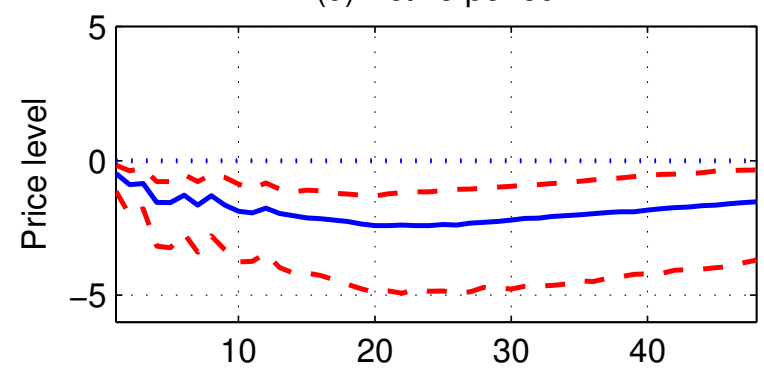

(f) Active period

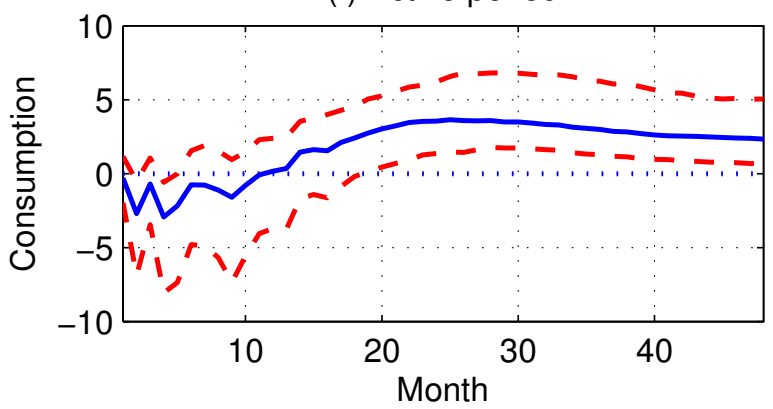

Notes: The passive period is 1959-79; the active period is 1981-2002. The size of the excess return shock is chosen such that, in each period, the cumulative response of government spending over the first three years equals $10 \%$ of one year of average spending. The dashed lines envelope the $68 \%$ confidence intervals. 
Act. Specifically, the news of the Democratic presidential and congressional victories provided an innovation to expectations about future government spending. This spending took many months to ramp up, followed by several years of relatively consistent spending followed by a gradual winding down.

In contrast, exogenous spending identified by an alternative approach based on timing restrictions (e.g. Auerbach and Gorodnichenko (2012)) has not exhibited hump-shaped paths for spending. In the alternative approach, the typical pattern is that spending jumps up on impact and then smoothly returns to it steady state over time.

Panel (b) of Figure 3 contains the spending impulse response for the active policy sample. Relative to the passive period, it takes significantly longer for spending to reach its peak and much longer for spending to converge to the steady state. Thus, the pre-1980 military-driven spending changes were less persistent than those from after 1982.

In comparing the two samples, we seek to assess the importance of the expected inflation channel by examining a period when it should be strong (1959-79) to a period when it should be relatively weak (1981-2002).

Figure 3(c) shows the impulse response for the price level during the passive policy sample. The point estimates show that the price level increased slightly and then fell over the first two years following the start of the spending increase. This occurred despite the fact that monetary policy was highly accommodative during this entire time span. The $68 \%$ confidence interval contains the zero response throughout the four-year horizon.

Recapping, several existing papers have argued that government spending has a particularly large effect on economic activity when the nominal interest rate is stuck at zero; however, this feature arises more generally than simply when the nominal rate equals zero. It also occurs when monetary policy is passive. The channel works because government spending drives down the real rate through an increase in expected inflation. Figure 3(c) shows that increased government spending from an exogenous source did not cause substantial inflation during the passive policy era. Table 2 summarizes key statistics from the impulse responses. The point estimate of the one-year inflation response to the spending shock is $-0.08 \%$ with a $90 \%$ confidence interval of $(-1.39,1.65)$.

This response is substantially smaller than that suggested by the calibrated sticky price model. Table 1 (with $\kappa=0.02$ ) shows that in order to generate an output multiplier of 1.75 , the one-year expected inflation would increase by $3.42 \%$.

Figure 3(d) presents the inflation response during the active monetary policy sample. The pricelevel response is negative throughout the first four-years. Examining the corresponding confidence band, we reject the hypothesis that the price level increased in response to the excess return shock at the $68 \%$ level. Table 2 reports the point estimate and $90 \%$ confidence interval for the one-year inflation response. At the 12-month mark following the shock, the point estimate implies that the price level falls by $1.76 \%$. The $90 \%$ confidence interval is extremely wide $(-8.86,5.24)$. At this 
confidence level, we conclude that the data and identification strategy are not very informative about the expected inflation channel during the active policy period.

Panels (e) and (f) plot the consumption responses for the two samples. Using these impulse responses, it is straightforward to calculate the estimated (cumulative) consumption multipliers. ${ }^{6}$ The estimates are not very informative for either sample. The $90 \%$ confidence interval for the multiplier is $(-1.27,1.71)$ for the passive policy period and $(-4.44,5.53)$ for the active policy period (see Table 2). We cannot reject a zero or negative response of consumption. However, we also cannot reject a large multiplier. ${ }^{7}$

On its own, the VAR evidence does not reject a large consumption multiplier; however, the estimates do reject the expected inflation channel as a quantitatively important mechanism by which a large consumption multiplier might have been generated.

\subsection{Robustness}

Next, we conduct robustness checks of our VAR analysis. Overall, the key finding from our benchmark specification-that the empirical inflation response to a spending shock in the passive period is too small to support a large output multiplier-is confirmed in the alternative specifications. Table 3 contains the inflation responses. Table 4 contains the consumption responses. We focus our discussion below on the inflation response during the passive policy period because this is where the expected inflation channel hypothesis suggests that we should find the greatest response. The first row of Table 4 restates the benchmark finding. The second row of the table reports the inflation responses from the large-multiplier calibration of the sticky price model, computed in Section 2.1.

The third row displays modifications of the benchmark specification by moving to a 12 lag VAR. The point estimates in both passive and active policy periods are consistent with our benchmark results. The confidence intervals are wider relative to the benchmark specification.

Next, we modify the benchmark specification by moving to either 9 or 12 lags in the VAR, and replacing CPI level with CPI inflation. For each case, the point estimate under in the passive rule is nearly unchanged and the confidence interval tightens relative to the benchmark specification. For the active period, we find a higher inflation response and consumption multiplier; however, they are also inconsistent with large multiplier sticky price calibration. With either 9 or 12 lags, the confidence interval for the consumption multiplier is so large as to not be very informative.

Continuing to work downward in Table 3, we next use the Blanchard-Perotti identification method; thus, we remove the excess return variable and impose a recursive timing structure where government spending is ordered first. That is, a government spending shock is assumed to engender no within period changes in the other variables. For the passive period, the $90 \%$ confidence intervals for the inflation responses and consumption multipliers are in line with the evidence from our

\footnotetext{
${ }^{6}$ See Section 2.1 .

${ }^{7}$ We also estimated the benchmark specification except we use an extended active policy sample (1981-2008). In this case, the point estimates for the inflation response and consumption multiplier are -1.11 and 0.03 , respectively.
} 
Table 3: Estimates of the one-year inflation response (APR) to a government spending shock, structural VAR robustness analysis

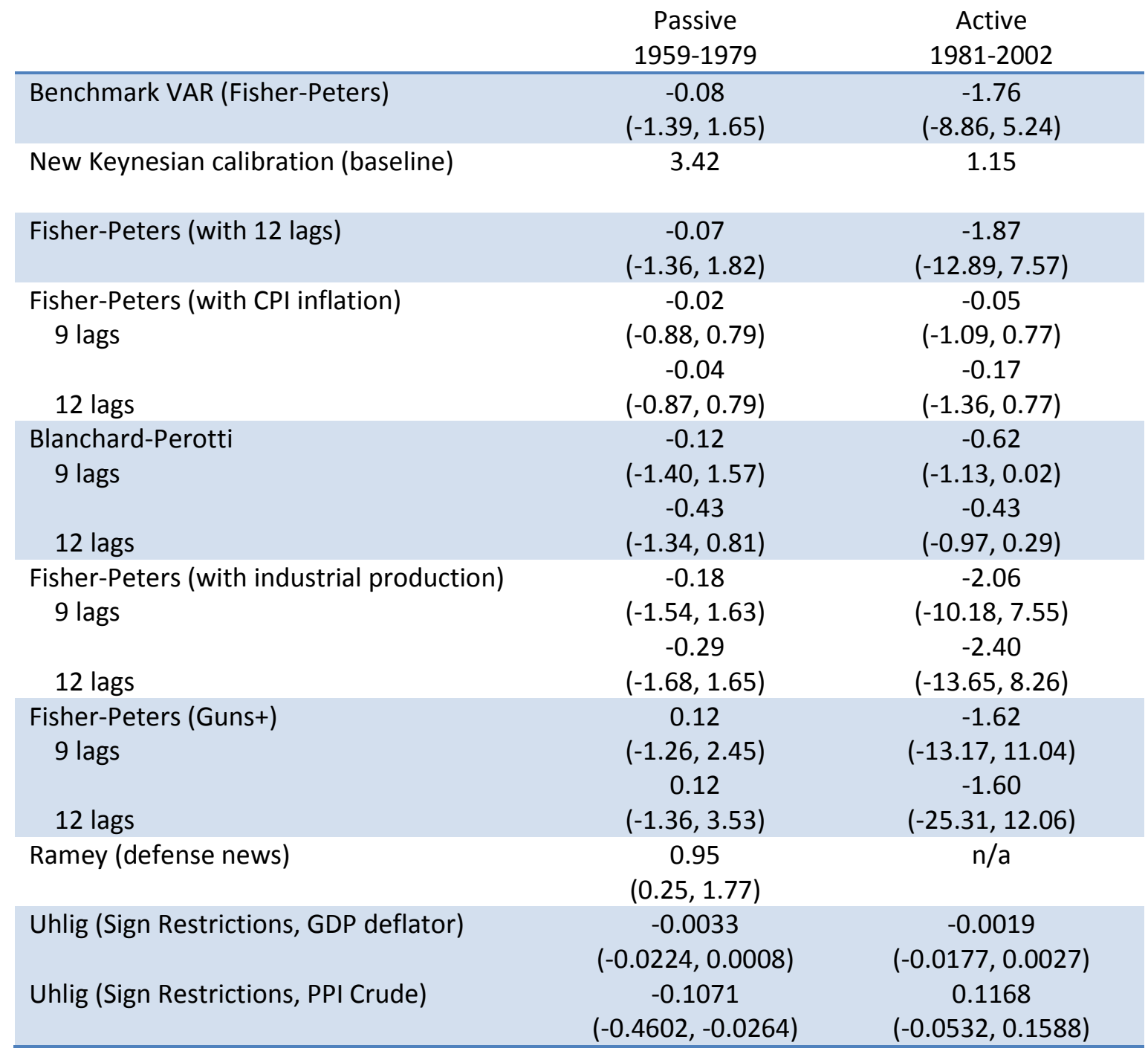

Notes: $90 \%$ confidence intervals appear in parentheses. 
Table 4: Estimates of the consumption multiplier, structural VAR robustness analysis

\begin{tabular}{lcc} 
& Passive & Active \\
& $1959-1979$ & $1981-2002$ \\
\hline Benchmark VAR (Fisher-Peters) & 0.35 & 1.63 \\
& $(-1.27,1.71)$ & $(-4.44,5.53)$ \\
New Keynesian calibration (baseline) & 0.75 & -0.25 \\
Fisher-Peters (with 12 lags) & 0.54 & \\
& & 2.37 \\
Fisher-Peters (with CPI inflation) & $(-1.04,1.91)$ & $(-5.76,9.76)$ \\
9 lags & 0.36 & 0.92 \\
& $(-7.06,8.82)$ & $(-19.65,14.79)$ \\
12 lags & 0.72 & 2.27 \\
Blanchard-Perotti & $(-4.86,6.09)$ & $(-5.94,9.67)$ \\
9 lags & 0.41 & 1.48 \\
12 lags & $(-0.73,1.49)$ & $(0.85,1.89)$ \\
Fisher-Peters (with industrial production) & 0.34 & 1.32 \\
9 lags & $(-1.07,1.38)$ & $(0.72,1.66)$ \\
& 0.25 & 2.29 \\
12 lags & $(-1.96,1.55)$ & $(-4.42,10.40)$ \\
Fisher-Peters (Guns+) & 0.60 & 2.34 \\
9 lags & $(-0.74,1.93)$ & $(-2.38,12.40)$ \\
12 lags & 0.38 & 1.79 \\
Uhlig (Sign Restrictions) & $(-1.63,1.90)$ & $(-6.86,12.75)$ \\
& 0.71 & 2.20 \\
\hline
\end{tabular}

Notes: $90 \%$ confidence intervals appear in parentheses. The consumption multiplier is the cumulative response of consumption divided by the cumulative response of government spending, each summed over the first 3 years following the shock. 
benchmark specification. For the active period, this identification method provides a higher (but still negative) inflation response, and a smaller consumption multiplier.

Next, we use the Fisher-Peters identification, but add industrial production to the vector of observables. For both inflation response and consumption multiplier, the $90 \%$ confidence intervals are in line with our benchmark specification; however, due to the large confidence interval, the data and identification strategy are not very informative about the expected inflation channel during the active policy period.

Next, we replace the accumulated excess returns of the "top three" firms from our benchmark model with those of the "Guns+" firms. In Fisher and Peters (2010), the "Guns+" category is defined to include all of the publicly traded companies that operate within a set of SIC coded to the military industries. ${ }^{8}$ For the passive period and using 9 lags, the point estimate and confidence interval of the one-year inflation response and consumption multiplier are in line with the results from our benchmark specification. The confidence intervals from the specification with 12 lags are wider and consistent with either a small or large expected inflation channel.

We consider two additional approaches, each of which uses quarterly data. First, we use the defense news variable constructed by Ramey (2011) (based on a narrative approach), rather than the Fisher-Peters excess returns series. We follow the VAR specification in Ramey (2011). Our two modifications to her specification are: (i) we add the log consumer price index; (ii) we use only the pre-Volcker data that is in Ramey's sample. ${ }^{9}$ The point estimate of the inflation response during the passive period is 0.22 with a $90 \%$ C.I. given by $(-0.13,0.47)$. This is consistent with our benchmark finding. We do not include estimates for the active policy period in the tables. Because there is very little variation in the defense news series during the 1981-2002 period, the instrument is too weak to provide reliable results. We enter " $\mathrm{n} / \mathrm{a}$ " in the corresponding cells of Tables 3.

Second, we use the VAR sign restriction approach (see Uhlig (2005) and Mountford and Uhlig (2009)). We identify a positive government spending shock by requiring that government spending increases in response to the shocks and also that it is orthogonal to a business cycle shocks and a monetary policy shock. ${ }^{10}$

Following Mountford and Uhlig (2009), we use a 10 variable vector of observables. ${ }^{11}$ Their specification includes two nominal price indices: the GDP deflator and the PPI for crude materials. In Table 3 , we report the inflation responses corresponding to each index. For both the active policy and passive policy samples, there is either no quantitatively significant and/or no statistically

\footnotetext{
${ }^{8}$ These industries are listed in Footnote 2 of their paper.

${ }^{9}$ Specifically, we use 1947-1979 in order to capture as much exogenous variation as possible. See her paper for further details.

${ }^{10}$ The business cycle and monetary policy shocks are also identified with sign restrictions. A business cycle shock is required to jointly moves GDP, government revenue, private consumption, and private non-residential investment in the same direction for four quarters following the shock. A monetary policy shock is required to move the interest rate and reserves up as well as push prices downward for four quarters after the shock. The monetary policy shock is also required to be orthogonal to the business cycle shock.

${ }^{11}$ See their paper for further details on the data and the identification assumptions.
} 
significant response of inflation.

The key punch line of Table 3 is that the passive monetary policy calibration of the New Keynesian model exhibits a much larger response (i.e. 3.42) than those from the structural VARs, 1959-1979 sample, under alternative identification schemes.

\section{The Recovery Act Episode: Theory and Evidence}

\subsection{A Transiently Non-Responsive Policy (including the Zero Lower Bound)}

Consider an alternative monetary policy where the central bank maintains a constant interest rate for a pre-specified number of periods. After the last period, it switches to a policy of inflation and output stabilization. For $t>T$, assume that: (i) the fiscal authority sets government spending equal to its steady-state level and (ii) the monetary authority chooses an interest rate policy capable of stabilizing output and inflation at their steady-state levels. ${ }^{12}$

For $t \leq T$, the fiscal authority sets government spending according to $g_{t}=g^{H}>0$ and the monetary authority pegs $i_{t}=i^{H}$, which for simplicity we set equal to zero. ${ }^{13}$

Substituting out $c_{t}$ from (2.1) using (2.4), a perfect foresight equilibrium under the above policy can be expressed solely as a function of the inflation and government spending sequences:

$$
\begin{gathered}
\beta \sigma \pi_{t+2}-\{\chi+\sigma(1+\beta)\} \pi_{t+1}+\sigma \pi_{t}=0 \text { for } 0 \leq t<T-1 \\
\left\{\kappa\left[1+\frac{v}{\sigma}(1-s)\right]+(1+\beta)\right\} \pi_{T}=\pi_{T-1} \\
\pi_{T}=\omega g^{H}
\end{gathered}
$$

and $\pi_{t}=0$ for $t \geq T$. It is straightforward to show that there exists a unique equilibrium that remains within a neighborhood of the steady state. One can calculate $\left\{\pi_{t}\right\}_{t=0}^{T}$ by solving (2.1) through (2.3) backward. The solution takes the form

$$
\begin{gathered}
\pi_{t}=a_{t} g^{H} \\
y_{t}=b_{t} g^{H}
\end{gathered}
$$

To compute the inflation and output responses to government spending changes, we choose baseline parameters. The first four parameters are set as:

$$
\beta=0.995, \quad s=0.2, \quad \sigma=1, \quad v=4
$$

\footnotetext{
${ }^{12}$ Stabilization is possible because of the absence of shocks after time $t$.

${ }^{13}$ As one of many other alternatives, we could set $i^{H}=-\rho$, where $\rho$ is the rate of time preference. In this case, one could think of the interest rate as one chosen to be zero or else "stuck" at zero because of a constraint on the monetary authority. For the purposes of developing inflation responses and output multipliers in this paper, the particular choice of $i^{H}$ is not critical.
} 
Next, we set $\kappa=0.0164$ as our baseline value. This value is well within the range of existing studies. We chose this value in order to generate a high output multiplier, allowing us to analyze the expected inflation channel quantitatively.

Finally, we specify the size and duration of the government spending shock. Our goal is to at least roughly match the size and duration of the Recovery Act. ${ }^{14}$ First, we choose $T=11$, since most of the Act's government spending component occurred within the 12 quarters following the law's passage. Next, the government spending component of the Act was equal to $10 \%$ of a one-year level of government spending (equivalently $40 \%$ of one-quarter of government spending). ${ }^{15}$ Spread across 12 quarters, this implies $g^{H}=0.40 / 12=0.033$. With the above information, we can solve for the equilibrium and compute the key statistics.

As part of our analysis, we define two specific output multipliers. The flow multiplier on impact, or alternatively the impact flow multiplier, is the time 0 response of output, to a one unit fixedduration spending shock:

$$
m_{0}=\frac{1}{s} b_{0}
$$

We call this the impact flow multiplier because it takes into account only the output and spending that occur in a particular quarter; it does not reflect the fact that the spending shock is an entire sequence. Note that the multiplier is independent of the magnitude of $g^{H}$; however, it does depend upon the duration of the spending increase. ${ }^{16}$

Next, we define the cumulative output multiplier, or simply the multiplier, as

$$
m_{C U M}=\frac{1}{s}\left(\frac{\sum_{j=0}^{T-1} b_{j}}{T}\right)
$$

The response of output at time 0 (as well as future periods) depends not only on the spending at time 0 , but also the spending in the remaining periods. With a dynamic model, we contend that the cumulative multiplier is more useful as a single measure of the overall stimulative effect (and cost) of government spending than other commonly used statistics, such as the impact flow multiplier or the peak multiplier.

The solid lines in Figure 4 are responses to the spending shock for the baseline, i.e. high multiplier, calibration. Panel (a) shows the accumulated flow multipliers. This is how many additional units of output, at a particular impulse horizon, have been created thus far relative to the amount of output purchased by the government thus far.

\footnotetext{
${ }^{14}$ The output multiplier will be independent of the size of the spending shock in the above policy. Since our goal is to examine the quantitative importance of the inflation channel for a particular episode, it is important to get the magnitude of the spending shock within a plausible range.

${ }^{15}$ Government consumption expenditures and gross investment equaled $\$ 3.09$ trillion in 2008 , according to the National Income and Product Accounts. Based on weekly federal agency reports (available at Recovery.gov), through the three year mark of the Act's passage, total obligations (excluding the Department of Labor) equaled $\$ 300$ billion. Obligations exclude tax benefits and direct entitlement payments to individuals.

${ }^{16}$ We divide the elasticity $b_{0}$ by $s$ so that the multiplier $m_{0}$ takes the form of a derivative.
} 
Figure 4: Output multipliers and impulse response to a Recovery Act sized spending shock, under alternative calibrations of a New Keynesian model

(a) accumulated flow output multiplier

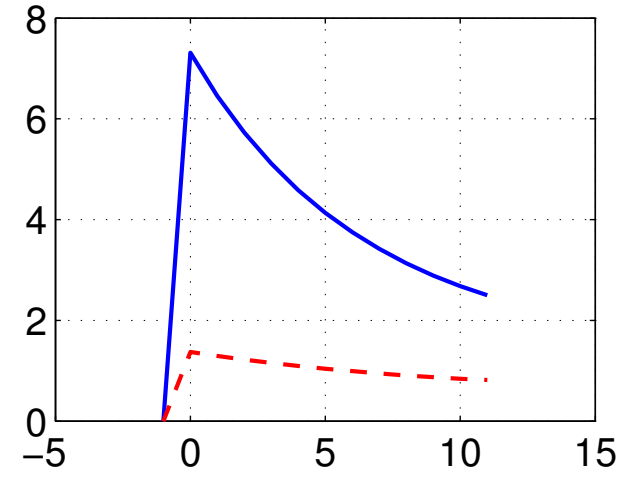

(b) flow output multiplier

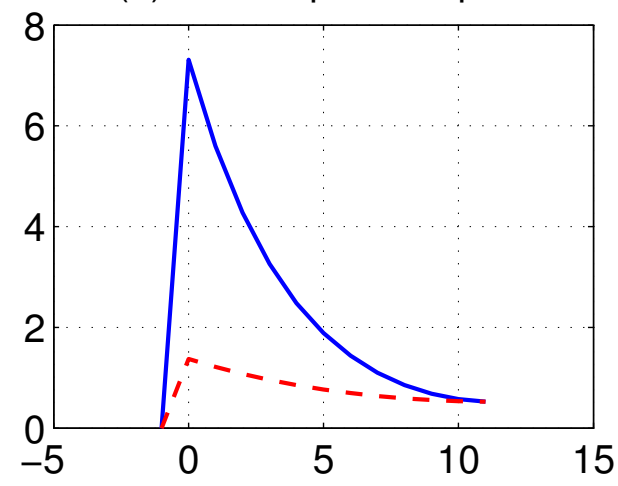

(c) price-level response

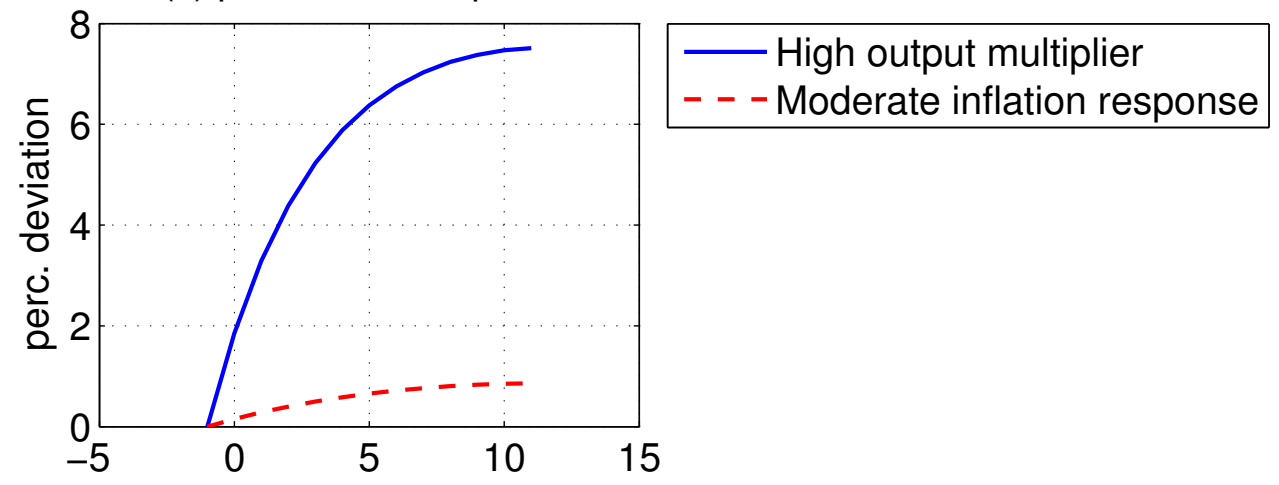

Notes: For the "high output multiplier" case, $\kappa$ is chosen to match an (accumulated flow) output multiplier equal to 2.5. For the "moderate inflation response" case, $\kappa$ is chosen to match a 50 basis point 1-year price-level response. 
Table 5: Responses of the expected price level and output to a Recovery Act sized government spending shock under a transitory interest rate peg

\begin{tabular}{|l|l|l|l|l|}
\hline Study & $\begin{array}{l}\text { Output } \\
\text { multiplier } \\
\text { (cumulative) }\end{array}$ & $\begin{array}{l}\text { Expected one- } \\
\text { year price level } \\
\text { response }\end{array}$ & $\begin{array}{l}\text { Flow output } \\
\text { multiplier } \\
\text { (on impact) }\end{array}$ & $\begin{array}{l}\text { Expected } \\
\text { duration of } \\
\text { spending shock } \\
\text { (in years) }\end{array}$ \\
\hline $\begin{array}{l}\text { This paper (baseline) } \\
\text { High multiplier calibration }\end{array}$ & 2.5 & $5.23 \%$ & 7.3 & 3.0 \\
\hline $\begin{array}{l}\text { This paper } \\
\text { Moderate expected } \\
\text { inflation calibration }\end{array}$ & 0.8 & $0.50 \%$ & 1.4 & 3.0 \\
\hline $\begin{array}{l}\text { Christiano, et.al. } \\
\text { (Section 3, 2011) }\end{array}$ & 3.7 & $3.50 \%$ & 3.7 & 1.25 \\
\hline
\end{tabular}

Notes: For each specification, the shock entails cumulative expected government spending equal to $10 \%$ of one year of steady-state government spending. In each case, the interest rate peg lasts as long as the spending stimulus is in effect. Christiano, Eichenbaum and Rebelo (2011) assume random duration fiscal and monetary polices.

At period $T$ and thereafter, the value equals the cumulative output multiplier (or simply the multiplier), which is 2.5. The dashed line is the corresponding response under less flexible prices $\kappa=0.0035$, which generates a more moderate inflation response. The corresponding cumulative multiplier is 0.8 . For the more modest expected inflation response, the implied output multiplier is less than 1. Table 5 reports numerical values for some of the lines plotted in Figure 4.

The solid line in panel (c) of Figure 4 contains the price-level response for the high multiplier calibration. The response is very large: the inflation rate during the first year is $5.23 \%$ (Table $5)$. This response is required to generate a sufficient real interest rate decline to cause the large consumption boom.

In the next subsection, we look at expected inflation data before and after news of and passage of the Act. Previewing our results, the evidence suggests a 0 to 50 bp increase in expected inflation rather than the 523 bp increase implied by the high-multiplier calibration.

The dashed lines in Figure 4 provide the impulse responses and output multipliers consistent for the moderate expected inflation case. For the moderate multiplier case, the inflation response is $0.5 \%$ (50 bps).

Table 5 also contains the corresponding statistics from an existing study by Christiano, Eichenbaum and Rebelo (2011) on the output multiplier. Their model is similar to ours, with three differences: (i) it uses a somewhat different calibration from ours; (ii) it uses a "random duration" monetary/fiscal policy rather than one of fixed duration, and (iii) it uses preferences that are 
nonseparable in consumption and leisure. ${ }^{17}$

Under the random government policy, $g_{0}=\tilde{g}^{H}$ and $i_{0}=0$. Thereafter, the process is as follows:

$$
\begin{aligned}
\operatorname{Pr}\left(g_{t+1}=\tilde{g}^{H} \text { and } i_{t+1}=0 \mid g_{t}=\tilde{g}^{H}\right) & =\phi \\
\operatorname{Pr}\left[\left(g_{t+1}, y_{t+1}, \pi_{t+1}\right)=(0,0,0) \mid g_{t}=0\right] & =1-\phi \\
\operatorname{Pr}\left[\left(g_{t+1}, y_{t+1}, \pi_{t+1}\right)=(0,0,0) \mid g_{t}=0\right] & =1
\end{aligned}
$$

The model dynamics are once again described by (2.1) through (2.3), except that time $t+1$ variables are now conditioned on time $t$ expectations. Thus, the government chooses an interest rate peg and high government spending each period until a random time in the future. At that point, the government switches permanently to zero spending and perfect inflation-output stabilization.

The locally unique equilibrium takes the form

$$
\pi_{t}=\tilde{a} g_{t} \text { and } y_{t}=\tilde{b} g_{t}
$$

for all $t .^{18}$

For the deterministic policy, we had $g^{H}=0.033$ and $T=11$, which resulted in a policy action with total government spending equal to $10 \%$ of one year of steady-state government spending. Our analogue for the random policy will be that the expected total government spending equals 10\%. Thus, we select $\tilde{g}^{H}=0.4 /(1-\phi) .{ }^{19,20}$

For the random policy, the flow multiplier on impact is simply $\tilde{m}_{0}=\tilde{b} / s$. The previous definition of the cumulative multiplier necessitates an adjustment because policy is random. We define the cumulative multiplier, with respect to the random policy, to be the ratio of expected cumulative responses. It becomes the ratio of the sum of the expected output responses over time relative to the sum of the expected government spending over time, denoted as

$$
\tilde{m}_{C U M}=\frac{1}{s}\left(\frac{\sum_{j=0}^{\infty} \phi^{j} \tilde{b}}{\sum_{j=0}^{\infty} \phi^{j}}\right)=\frac{1}{s} \tilde{b}_{0}
$$

Thus, for random policy, the cumulative multiplier equals the impact flow multiplier $\tilde{m}_{0}=\tilde{m}_{C U M}$.

For the purpose of fitting a Recovery Act type policy to the model, our choice of a fixed-

\footnotetext{
${ }^{17}$ The above calculation is from the Christiano, Eichenbaum and Rebelo (2011) model without capital. Christiano, Eichenbaum and Rebelo (2011) also presents two models with capital. We are unable report inflation responses for these latter models. Analyzing the expected inflation channel in models with capital merits further research.

${ }^{18}$ Some constellations of parameters result in local indeterminacy. As in Christiano, Eichenbaum and Rebelo (2011), we do not consider parameterizations within this range in our simulations.

${ }^{19}$ Rather than changing the spending-per-period, we could change the continuation probability of the policy shock. We chose the former because of the sensitivity of the multiplier to this probability. See Carlstrom, Fuerst and Paustian (2012) for a detailed discussion on this sensitivity as well as the sensitivity to whether a fiscal/monetary policy has a random versus fixed duration. Note that the multiplier is independent of the value of $g^{H}$.

${ }^{20}$ In our notation, Christiano, Eichenbaum and Rebelo (2011) set $\phi=0.903$ and $\phi=0.8$, respectively.
} 
duration policy, as opposed to a random one, is more appropriate. There was neither a "random" nor "conditional on continuing macro weakness" legislative language in the Act; moreover, political changes soon after the Act's passage excluded future federal spending stimulus. First, in January 2010, the special election of Republican Scott Brown to the Senate ended the Senate's Democratic super-majority. In January 2011, the Republican takeover of the U.S. House of Representatives provided a second block to further spending stimulus.

Moreover, when the Act became law, the non-responsive interest rate policy was also better described as fixed as opposed to random duration. In the Federal Open Market Committee press release from March 2009, close in time to the Act's passage, the Committee restated its commitment to forward guidance, stating it would "maintain the target range for the federal funds rate at 0 to $1 / 4$ percent" and foresaw "exceptionally low levels of the federal funds rate for an extended period." 21

The final row in Table 5 contains the corresponding statistics for the baseline calibration from Christiano, Eichenbaum and Rebelo (2011). ${ }^{22}$ They use the random duration policy described above and find a high output multiplier, 3.7. For the spending shock with the size described above, they find a very strong expected inflation response: $3.5 \%$.

In the next section, we ask whether the expected inflation data during the Recovery Act period are consistent with a significant expected inflation response.

\subsection{Background Information on the Act and the Inflation Facts}

Since the expected inflation channel is crucial for generating a large output multiplier in the previous model simulations, we examine the change in inflation expectations upon the arrival of news of the Recovery Act. Fortunately, the political environment during this period implies that we can plausibly isolate the timing of news arrival of a large federal spending program to 2008:Q3 - 2009:Q1.

First, the enactment of a large Keynesian spending program required election victories of spending proponents in the November 2008 presidential and congressional elections. Even until late in the election season, it was not clear how well these candidates, almost exclusively Democrats, would fare. Also, then-President George W. Bush, Republican presidential candidate John McCain, as well as most Republican congressmen and candidates, were firmly opposed a large spending program. ${ }^{23}$

Figure 5 plots consumer price index (CPI) inflation and core CPI inflation over the period of interest. ${ }^{24}$ The letter "B" demarcates 2009:Q1, which contains the month that the Act passed

\footnotetext{
${ }^{21}$ In its June 2011 press release, the Committee first began putting a specific end date (mid-2013 at the earliest) for continuing its nonresponsive interest rate policy.

${ }^{22}$ These numbers are calculated based on the parameter calibration used in their original paper.

${ }^{23}$ President Bush's response to the 2007-08 recession was a tax rebate program enacted in February 2008 at a cost of $\$ 152$ billion. The fact that it occurred a full year before the Recovery Act implies that it is unlikely that one would confound this earlier program's effect with that of the Recovery Act.

${ }^{24}$ For both series, we plot the three-month growth rate in the end-of-quarter CPI, which we have annualized.
} 
(February). The solid line is the core inflation rate, which fluctuates only slightly during the quarters surrounding the Democrat victory and the Act's passage. It gives no indication that the economy was entering into a substantial, long-lasting deflation.

In the following three years, the core inflation rate stays within the range of 0 and $2 \%$. The dash-dotted line is the headline inflation rate. There was a major decrease in the price level during 2008:Q4; however, this was due to a substantial fall in oil prices rather than a general decrease in prices.

Suppose the sticky price model, using the high multiplier calibration, is quantitatively accurate. Ceteris paribus, one would expect to have seen a large increase in the inflation rate following either the news or passage of the Act; however, this did not occur.

Another possibility, if the output multiplier was high as a result of the expected inflation channel, is that the Act reversed an expected deflation that would have occurred in its absence. Given our calculations in the previous section, the level of such an expected deflation would have had to approach that of the Great Depression. That price decline had been unprecedented; over the course of 1929 , the consumer price index fell by $6.6 \%$.

We next show that neither the election outcome nor the Act's passage was associated with a major change in expected inflation. Figure 6 plots the median value of expected inflation from the SPF, between 2007 and 2012, at two different forecasting horizons. ${ }^{25}$ The diamond-labeled line is the 1-year-ahead inflation expectation forecast. While expected inflation was relatively constant at approximately 2.5\% during both 2007 and early 2008, there was a decline of inflation expectations of roughly 90 basis points between 2008:Q2 and 2008:Q4. This decrease occurs concurrent with the economic slowdown.

Between the election (2008:Q4) and the Act's passage (2009:Q1), 1-year-ahead inflation expectations changed very little. The 5-year-ahead inflation expectations (the solid line) are nearly unchanged at roughly $2.5 \%$ both during the economic downturn as well as the Recovery Act period. In the six months following the Act's passage, expected inflation increased by only 25 basis points. In the six months following Obama's election victory, expected inflation fell by 5 basis points. Thus, the median forecast gives no indication that the Recovery Act turned around what would have otherwise been a historic deflationary spiral.

Next, we consider cross-country data that informs our question. One often-used measure of inflation expectations is the break-even inflation rate, defined as the yield spread between a nominal and inflation-indexed government bond. Bonds of both types and issued by both the U.K. and U.S. were traded throughout the Recovery Act period. The two countries provide a useful comparison because while both countries experienced recessions during this period, the U.K. - unlike the U.S.-

\footnotetext{
${ }^{25}$ As explained in Federal Reserve Bank of Philadelphia (2012), the "First Quarter" survey is sent to panelists at the end of January and the deadline for submission is the second to third week of February. Therefore, the last quarter in the panelists' information set is Q4 of the preceding year. The scheduling for the second, third and fourth quarterly surveys follow similarly.
} 
Figure 5: Headline and core inflation in the U.S. 2007-2011

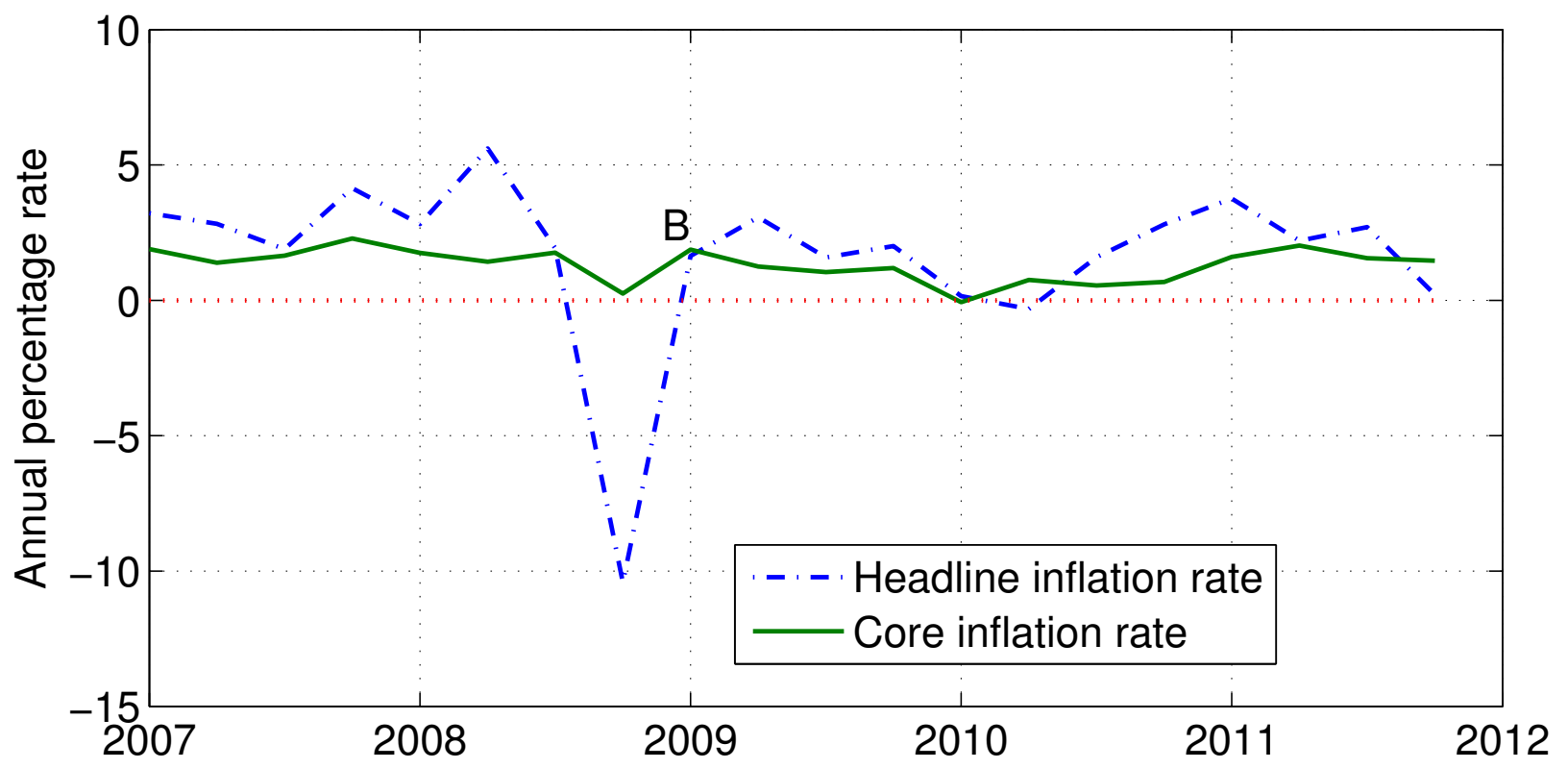

Notes: 'B' marks February 2009, the month of the passage of the Recovery Act.

Figure 6: Median forecast of one- and five-year ahead inflation from the Survey of Professional Forecasters, 2007-2011

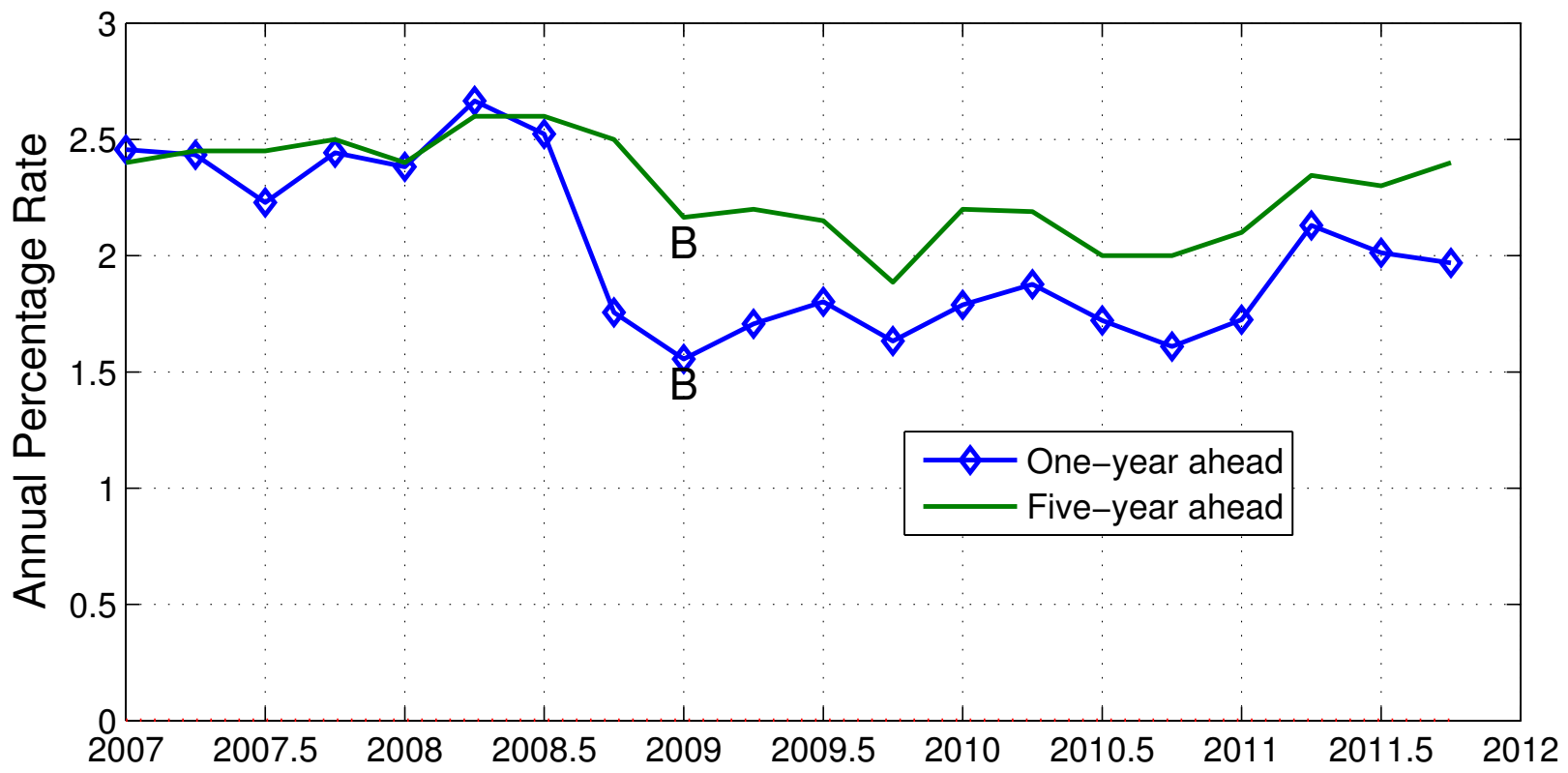

Notes: 'B' marks February 2009, the month of the passage of the Recovery Act. 
did not enact a major Keynesian spending program.

The impact of recessions in each country can be seen in their unemployment rates (Figure 7(a)). The unemployment rate in the U.S. increased by roughly 5\% between 2008 and 2010; in the U.K., it increased by roughly $3 \%$ over the same period.

Figure 7(b) contains the detrended real government spending for each country between 2005 and $2011 .^{26}$ Government spending in the U.S. was between $2 \%$ and $3 \%$ above trend for much of the Recovery Act period. On the other hand, there was no major short-run spending stimulus in the U.K. over the same period, as evidenced by the solid line in Figure 7(b). Both countries experienced recessions; only one carried out Keynesian spending.

Figure 7(c) plots the nominal-indexed yield spread for each government's bond.. This difference is the break-even inflation rate, which is often used to measure expected inflation. Consider the break-even inflation rate in the U.S (the diamond-labeled line). From the beginning of through the fall of 2008, break-even inflation in the U.S. fell from roughly $2.5 \%$ to $-1.5 \%$. This is consistent with the market participants forecasting a decline in the price level. During the three months that followed, roughly following the Democrat presidential and congressional victories, U.S. break-even inflation increased by roughly $2 \%$. Considered in isolation, this is qualitatively consistent with the expected inflation channel. That is, the political wins signaled news of an upcoming Keynesian stimulus, which bid up the expected future real wage relative to a no-stimulus baseline. In turn, increased marginal cost would cause future nominal price increases.

However, in the U.K. there was a similar increase in expected inflation over the same three months, despite the fact that the U.K. had no substantial short-run spending stimulus. The British government's primary anti-recession instrument was a temporary reduction in the value-added tax rate. It took effect through the Value Added Tax (Change of Rate) Order in December 2008 and was then extended as part of the Finance Act 2009. The Finance Act 2009 included only a few spending programs, such as £1B to support the green-energy sector.

The U.K. experience is counterevidence to a strong expected inflation channel in the U.S. Had the U.S. expected inflation (here measured by break-even inflation) increase been driven by the Recovery Act, then the channel suggests that the U.K. should have entered a deflationary spiral following the absence of a British Keynesian stimulus.

Next, we explain why the jump in U.S. break-even inflation seen in Figure 7(c) was more likely due to another factor rather than news of the Recovery Act. ${ }^{27}$ First, the major decrease and then increase of the U.S. nominal-indexed yield spread in 2008 came largely from a rise and then decline in the yield on indexed bonds. Figure 8 plots the daily yield on that bond from September through December of 2008.

The rise in this yield occurred over a period of several months; however, most of the decline

\footnotetext{
${ }^{26}$ The detrending was executed using a Hodrick-Prescott filter on each logged series, where the filter was applied to the 1995-2011 sample.

${ }^{27}$ See Neely (2010) for a further discussion of the issue.
} 
Figure 7: Unemployment, government spending and expected inflation in the U.S. and U.K., 20052011

(a) Unemployment rate

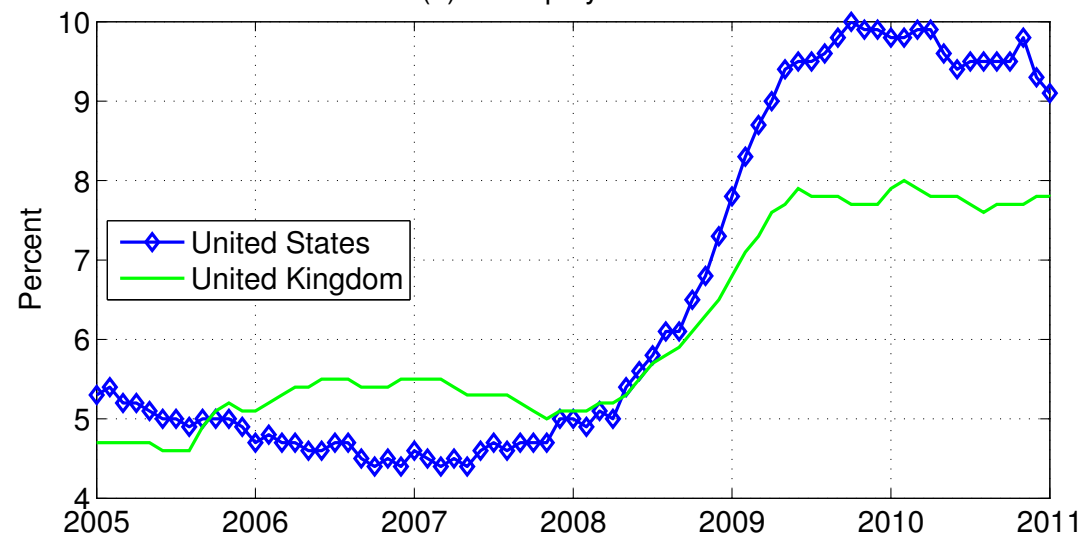

(b) Real government expenditure

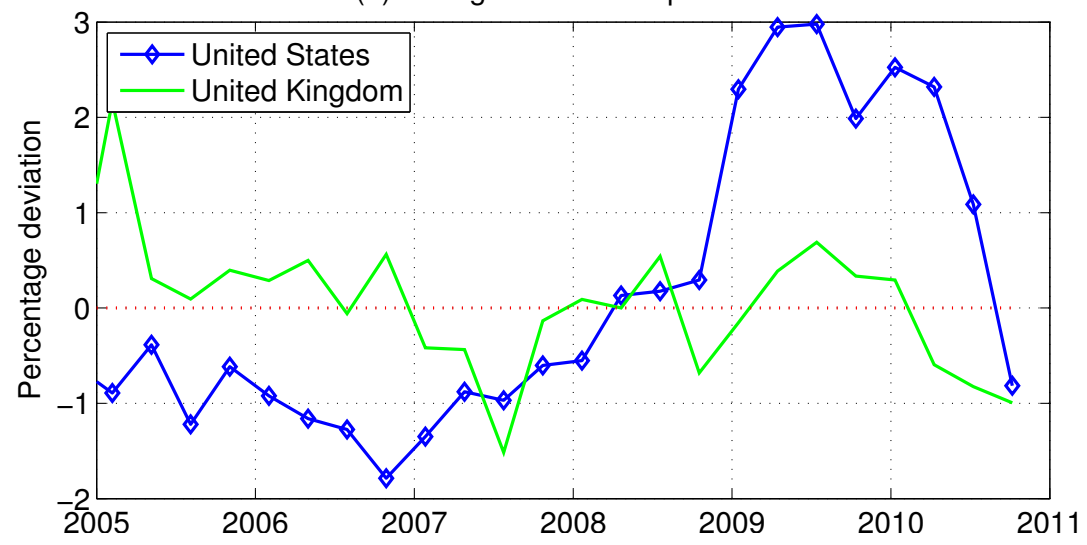

(c) Expected inflation (nominal-indexed yield spreads)

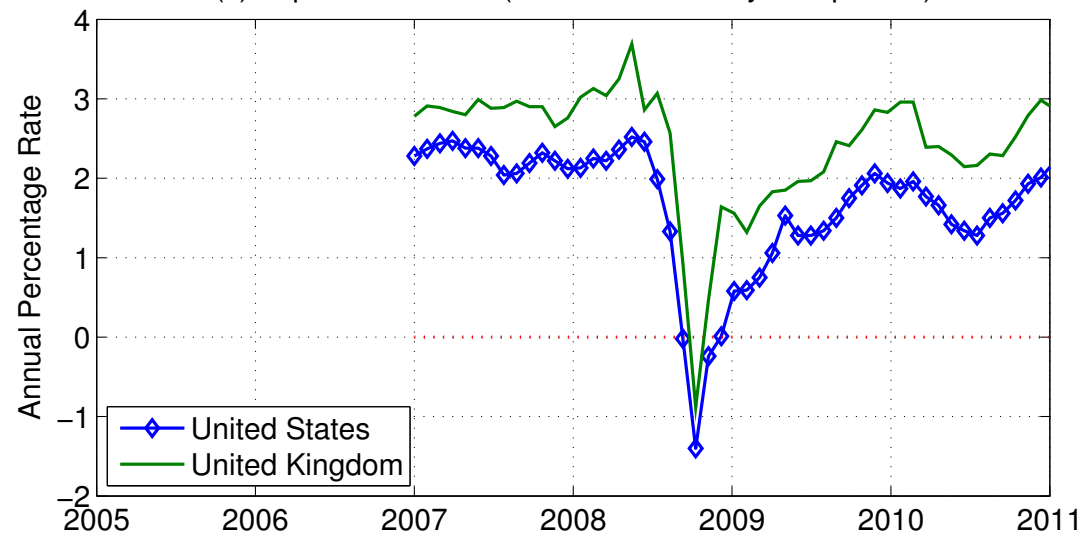

Note: Government spending is deviation of log spending from an Hodrick-Prescott trend. 
Figure 8: Daily yield on constant-maturity, five-year U.S. Treasury inflation-indexed bonds

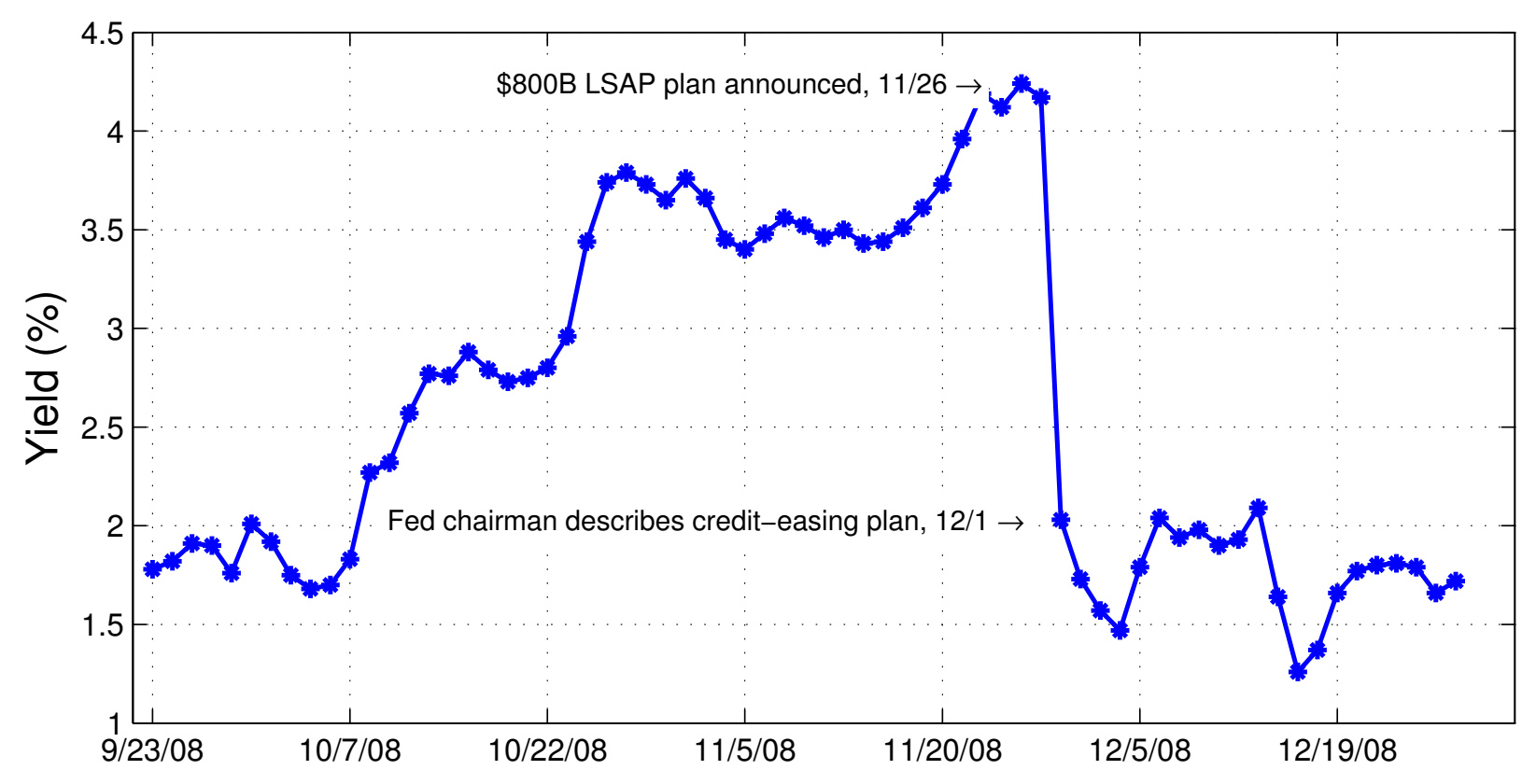

Notes: LSAP stands for "large scale asset purchases".

in that yield, and most of the rise in break-even inflation, occurred within a 3 trading day time span: Wednesday, November 26 to Monday, December $1 .^{28}$ On November 26, the Federal Reserve announced its plans to buy $\$ 800$ billion worth of mortgage-backed securities. December 1 marked Federal Reserve Chairman Ben Bernanke's speech to the Austin Chamber of Commerce, outlining his commitment to continued monetary easing. This included a commitment to continued largescale asset purchases along with further federal funds rate cuts.

The dramatic decline in the indexed bond yield aligns to the day with an historic unconventional monetary policy announcement. This leads us to ask whether any fiscal policy announcements preceding the Recovery Act aligned with major changes in break-even inflation.

\subsection{Isolating the Spending Shock using Fiscal Policy Announcements}

The November 26, 2008 Large Scale Asset Purchase announcement provided one instance where an interest rate moved dramatically at the time of important news about monetary/credit policy. This movement implied a large change in break-even inflation, which is sometimes interpreted as a change in inflation expectations. Along the same line of argument, if the expected inflation channel of fiscal policy were operative and quantitatively important one might predict that upward jumps in break-even inflation would occur at the time of expansionary fiscal policy news. We investigate

\footnotetext{
${ }^{28}$ Thanksgiving landed on November 27 of that year.
} 
Table 6: Significant fiscal policy news announcements preceding the 2009 Recovery Act

\begin{tabular}{|c|c|}
\hline Event & Date \\
\hline \multicolumn{2}{|l|}{2008} \\
\hline $\begin{array}{l}\text { (A) Then-candidates Obama and Biden release "A Rescue Plan for } \\
\text { the Middle Class," a stimulus plan estimated to cost } \$ 175 \text { billion }\end{array}$ & Oct. 12 \\
\hline $\begin{array}{l}\text { (B) First newspaper reports that congressional Democrats planning } \\
\text { to introduce stimulus plan costing } \$ 300 \text { billion. }\end{array}$ & Oct. 14 \\
\hline $\begin{array}{l}\text { (C) Obama wins presidency, Democrats achieve major gains in } \\
\text { Congress }\end{array}$ & Nov. 4 \\
\hline $\begin{array}{l}\text { (D) Obama gives address calling for decisive government action } \\
\text { including putting } 2 \text { million people to work rebuilding roads, bridges } \\
\text { and schools }\end{array}$ & Nov. 15 \\
\hline $\begin{array}{l}\text { (E) Senator Charles Schumer, Joint Economic Committee Chair, } \\
\text { states that stimulus would need to be between } \$ 500 \text { and } \$ 700 \\
\text { billion }\end{array}$ & Nov. 23 \\
\hline $\begin{array}{l}\text { (F) Obama announces first details of his recovery plan, including } \\
\text { some general categories }\end{array}$ & Dec. 6 \\
\hline \multicolumn{2}{|l|}{2009} \\
\hline (G) U.S. Senate approves the Recovery Act & Feb. 10 \\
\hline (H) Obama signs the Recovery Act into law & Feb. 18 \\
\hline
\end{tabular}

this possibility for the Recovery Act period.

To accomplish this, we examined newspaper articles, position papers and political speechesrecording the particular calendar dates that this information became available to the public. This narrative approach delivered eight distinct key news events from October 2008 through February 2009. These are presented in Table 6. The October 12 news was the release of then-candidates Barack Obama and Joe Biden's "Rescue Plan for the Middle Class." That plan was estimated to cost $\$ 175$ billion. Examples of other events include: Obama's presidential victory and major gains in Congress on November 3, Obama's announcement of the first details of his Recovery Plan on December 6, and the Senate passage of the Recovery Act on February 10.

Next, we calculate the daily break-even inflation rate using 5-year constant maturity bonds. By examining daily data, we are likely able to distinguish these announcements about fiscal policy from other shocks hitting the economy. Figure 9 plots the break-even inflation rate (APR) time path for each of the eight events. Each event corresponds to one line, marking the three (calendar) days before through three days after the event. A break in a particular line occurs when the corresponding time interval includes one or more non-trading days.

For all but one of the eight events, break-even inflation moves by less than 25 basis points from before to after announcement. At the time of Nov. 23 event, the Senate Joint Economic Committee Chair's announcement that a $\$ 500$ to $\$ 700$ billion stimulus would be necessary, break-even inflation increased 104 basis points. 
Figure 9: Break-even inflation rates (APR) in windows surrounding significant fiscal policy news announcements

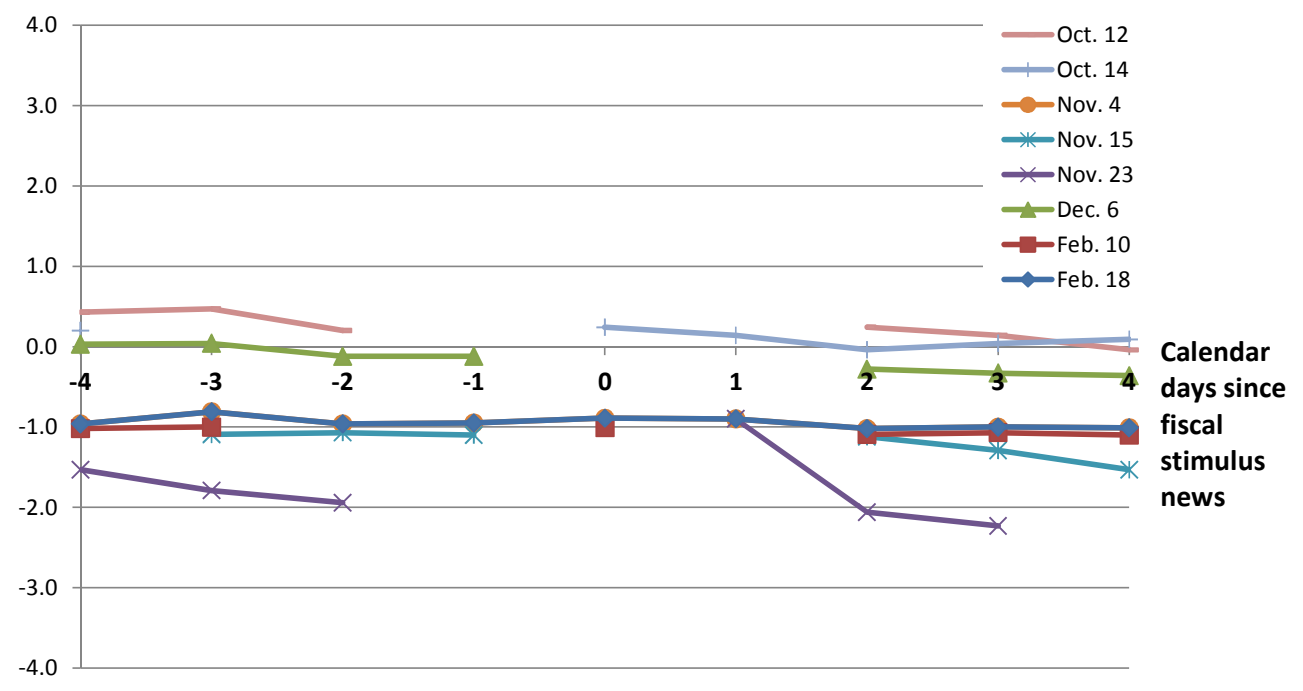

\subsection{Isolating the Spending Shock using Professional Forecasts}

The 2008-2009 path of the median value of professional forecasters' expected inflation presented earlier should be interpreted with caution because events other than spending changes may have influenced these forecasters' expectations. For example, one could imagine that news of the forthcoming Act (by itself) did substantially increase median inflation expectations, while over that same time frame, other "offsetting" news arrived that substantially decreased median inflation expectations. Together these two pieces of news might have summed to the observed small change in the quarter-to-quarter change in the median survey responses.

With this concern in mind, we next control for the aggregate time-specific factors that may have influenced the median forecast by examining the data at the individual forecaster level. The panel consists of 22 forecasters, each of whom completed surveys in 2008:Q3, 2008:Q4 and 2009:Q1 and whose responses included forecasts of federal government spending, total employment and inflation expectations.

According to the expected inflation channel, when one of the respondents began predicting a stimulus, then that respondent ought to simultaneously increase her inflation expectations. Some notation is useful here. Let $f_{t, j}(x)=E_{t}^{j}\left(x_{t+4}\right)-E_{t-1}^{j}\left(x_{t+3}\right)$ where $E_{t}^{j}$ denotes the expectation of forecaster $j$ at time $t$.

Table 7 reports $f_{t, j}(\pi)$ and $f_{t, j}\left(g^{G O V}\right)$, i.e. the change in the forecast, from one quarter to the next, of (i) 1-year expected inflation, and (ii) the 1 year-ahead growth rate of real federal 
Table 7: Change in forecasts of 1-year-ahead inflation and of 1-year-ahead federal government spending growth, by forecaster

\begin{tabular}{|c|c|c|c|c|c|c|}
\hline \multirow[b]{2}{*}{ Forecaster j } & \multicolumn{2}{|c|}{$\mathrm{t}=2008: \mathrm{Q} 4$} & \multicolumn{2}{|c|}{$\mathrm{t}=2009: \mathrm{Q} 1$} & \multicolumn{2}{|c|}{$\mathrm{t}=2009: \mathrm{Q} 2$} \\
\hline & $\begin{array}{c}\text { Gov. } \\
\text { spending }\end{array}$ & Inflation & $\begin{array}{c}\text { Gov. } \\
\text { spending }\end{array}$ & Inflation & $\begin{array}{c}\text { Gov. } \\
\text { spending }\end{array}$ & Inflation \\
\hline 1 & 0.4 & -0.5 & 13.1 & -0.6 & -2.9 & 0.0 \\
\hline 2 & 9.3 & 0.2 & 1.5 & -0.7 & -1.9 & 0.1 \\
\hline 3 & 1.4 & 1.1 & 8.4 & -0.1 & 0.0 & -0.2 \\
\hline 4 & 0.2 & 0.6 & 4.3 & -1.2 & 0.3 & -0.3 \\
\hline 5 & 0.9 & -0.5 & 4.2 & -1.8 & -1.8 & 1.1 \\
\hline 6 & 3.8 & 0.1 & 3.7 & 0.3 & 1.2 & -0.2 \\
\hline 7 & -0.2 & -1.1 & 2.0 & 0.0 & 3.8 & -0.0 \\
\hline 8 & 2.0 & 0.3 & 3.8 & 0.6 & 0.4 & -0.4 \\
\hline 9 & 0.8 & -0.6 & 3.3 & -0.3 & -1.8 & 0.2 \\
\hline 10 & 2.9 & 0.1 & 0.2 & -2.8 & -0.7 & 2.2 \\
\hline 11 & -0.0 & -2.1 & 1.8 & -0.7 & 2.9 & 0.6 \\
\hline 12 & -0.8 & 0.6 & -0.4 & 0.2 & 2.7 & -0.7 \\
\hline 13 & 0.4 & 0.2 & 2.3 & 0.0 & -0.9 & 1.1 \\
\hline 14 & 1.9 & -0.7 & -0.4 & 0.5 & 1.0 & -2.0 \\
\hline 15 & 1.7 & 0.4 & 1.0 & -0.7 & -0.6 & -0.2 \\
\hline
\end{tabular}

Notes: Government spending column values are $E_{t}^{j}\left(g_{t+4}^{\mathrm{Gov}}\right)-E_{t-1}^{j}\left(g_{t+3}^{\mathrm{Gov}}\right)$, where $j$ denotes the forecaster. Inflation column values are $E_{t}^{j}\left(\pi_{t+4}\right)-E_{t-1}^{j}\left(\pi_{t+3}\right)$. Values in bold indicate the time associated with the largest change in the forecast of government spending growth, by forecaster. The table excludes forecasters with very small changes in their forecasts of government spending growth.

expenditures. $^{29}$

Each pair of columns corresponds to a particular survey quarter. Each row corresponds to a forecaster; for each forecaster, numbers set in bold reflect the data for the quarter at which the forecaster has the largest increase in her spending growth forecast.

Consider, for example, Forecaster 2. Forecaster 2 reported an increase in 1-year-ahead expected government spending growth of 9.3\% in the 2008:Q4 survey. In the following quarter, Forecaster 2 predicted a modest $1.5 \%$ increase in her forecast of government spending growth. We interpret the 9.3\% increase as reflecting the forecaster responding to news of a potential, upcoming Keynesian stimulus. Examining the table, Forecaster 2 increased her inflation expectations in 2008:Q4 by only 20 basis points relative to the previous quarter.

Examining Table 7, we see that 12 of the forecasters predicted large increases (at least 2.5\%) from one survey quarter to the next in the annual growth rate of government spending. There was dispersion across forecasters in both the timing and the magnitude of their projected spending

\footnotetext{
${ }^{29}$ To conserve space, we exclude from the table the respondents who reported very little change in government spending expectation.
} 
Table 8: Estimates of response of innovation to 1-year-ahead inflation forecast with respect to a 1 percent positive innovation to expected government spending growth forecast

\begin{tabular}{|c|c|c|c|}
\hline \multirow[b]{2}{*}{$\begin{array}{l}\text { Survey quarter(s) } \\
\text { used }\end{array}$} & \multicolumn{2}{|c|}{ Cross Section } & \multirow{2}{*}{$\begin{array}{c}\text { Panel } \\
\text { 2008:Q3, 2008:Q4, } \\
\text { 2009:Q1 } \\
\text { (iii) }\end{array}$} \\
\hline & 2008:Q4 & $\begin{array}{l}\text { Forecaster largest } \\
\text { response quarter } \\
\text { (ii) }\end{array}$ & \\
\hline Forecast innovation & -0.012 & 0.029 & -0.011 \\
\hline to $\Delta$ gov. spending & $(0.054)$ & $(0.050)$ & $(0.043)$ \\
\hline $90 \% \mathrm{Cl}$ & {$[-0.125,0.100]$} & {$[-0.076,0.133]$} & {$[-0.098,0.075]$} \\
\hline Time fixed effects? & No & No & Yes \\
\hline$R^{2}$ & 0.002 & 0.010 & 0.104 \\
\hline
\end{tabular}

Note: Data are from the Survey of Professional Forecasters.

increases; however, none of these increases was associated with a large increase in expected inflation. The largest increase in expected inflation at one of these spikes was 60 basis points.

Next, we run regressions using this forecaster-level data. Our first specification is

$$
f_{t, j}(\pi)=a+b \times f_{t, j}\left(g^{G O V}\right)+\varepsilon_{t, j}
$$

Column (i) of Table 8 reports $\hat{b}$ when the forecast quarter is 2008:Q4. This is the quarter when the Democrats won the White House and Congress, making a federal spending program much more likely. The point estimate is -0.012 , which means that a 1 percent positive innovation to a forecaster's expected government spending over the following year was associated with a 1.2 basis point reduction in her 1-year-ahead inflation forecast. The response is not statistically different from zero.

Column (ii) uses the same regression with one exception. Rather than choosing the same forecast quarter for each forecaster, the time index for each forecaster is chosen based on each forecaster's largest spending innovation, (i.e. the bold-faced numbers in Table 7). ${ }^{30}$

The point estimate is 0.029 . This means that a $1 \%$ unanticipated increase in expected government spending growth is associated with a 2.9 basis point increase in expected inflation. The coefficient is not statistically different from zero.

Since the Recovery Act constituted a roughly 3.3\% increase in government spending (each year for three years), the point estimate suggests that the Act was associated with an 8.7 basis point $(=3.3 \times 2.9$ basis points $)$ increase in expected inflation. The $90 \%$ confidence interval for

\footnotetext{
${ }^{30}$ The sample also includes the data for the seven forecasters not included in the table.
} 
Figure 10: Scatter plots of changes in forecasts of 1-year-ahead inflation and of 1-year-ahead federal government spending growth
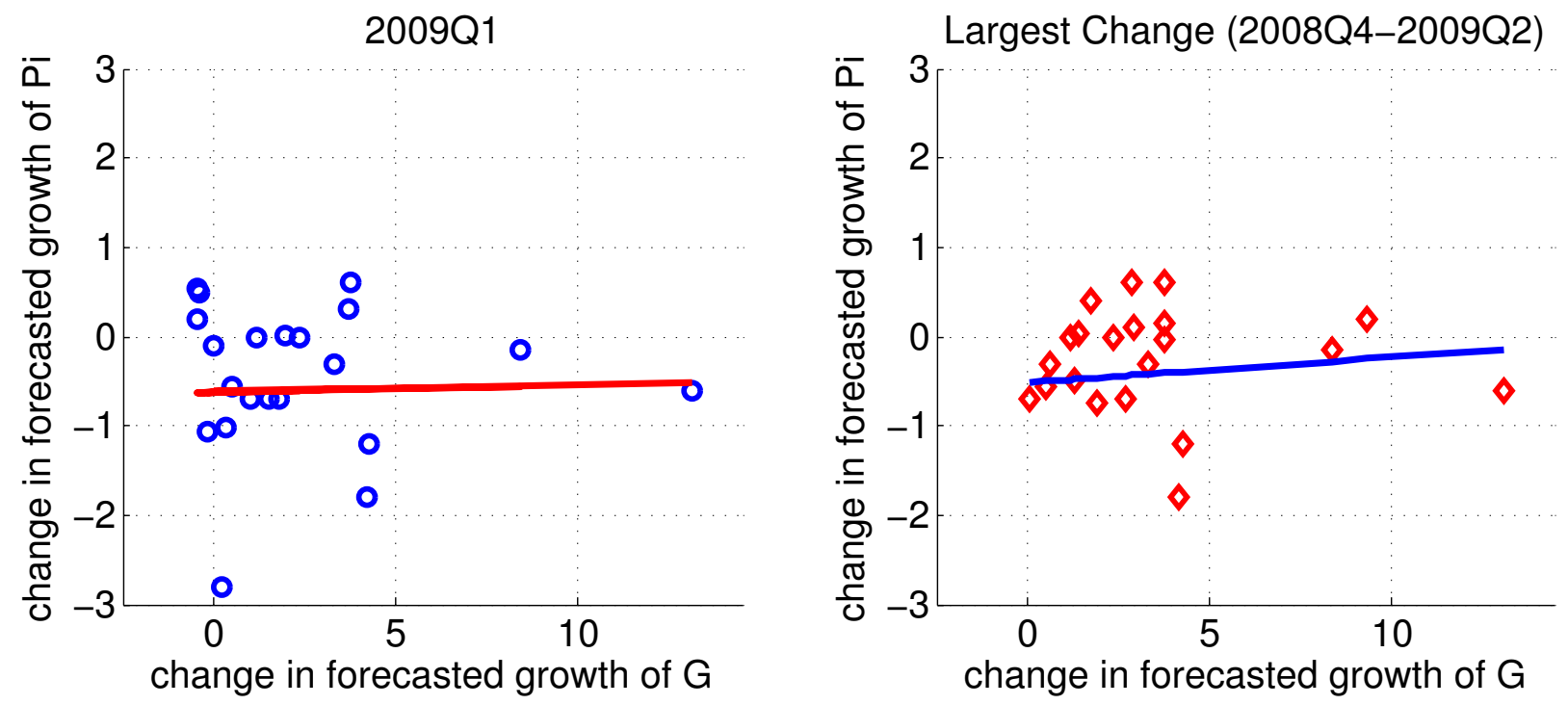

Note: Data are from the Survey of Professional Forecasters. The sample also includes data from all 22 forecasters.

this elasticity is $(-0.08 \%,+0.13 \%)$. Using the upper bound of this confidence interval, a spending increase with a magnitude of the Recovery Act would be associated with an increase in expected inflation of 43 basis points. ${ }^{31}$

Column (iii) reports the estimated response when the entire panel is used and we include time fixed effects. The results are similar to the two cross-sectional specifications. Thus, both the panel and cross-sectional estimates imply that we can reject a large expected inflation response to the Act.

Figure 10 provides two scatter plots and best fit regression lines for the panel data. It shows the same lack of correlation between forecasters' change in expected inflation and their change in government spending growth.

\footnotetext{
${ }^{31}$ Note that if we take the index $f_{t, j}$ forward one period, there is both a change in the conditioning information and also a shift forward in the random variable by one quarter. If we wish to perfectly isolate the change in information, we could use a more sophisticated measure. For the inflation innovation, we would have

$$
\tilde{f}_{t, j}\left(P_{t+3} / P_{t}\right)=E_{t}^{j}\left(P_{t+3} / P_{t}\right)-E_{t-1}^{j}\left(P_{t+3} / P_{t}\right)
$$

Using this measure would mean we would only be able to use 3-quarter-ahead, instead of our 4-quarter-ahead, inflation and spending growth measures. In results not presented here, we have shown that using $\tilde{f}_{t, j}(x)$ has negligible effects on our results.
} 


\section{Existing Research in the Context of Our Work}

This section describes existing work that is relevant to our study. First, Erceg and Linde (2012) document how the expected inflation channel can lead to a large output multiplier, while simultaneously having minimal government budgetary costs when an economy is at the zero lower bound. They then ask why, given the effectiveness of these policies, do policymakers limit the size of their spending programs under these circumstances? Their answer is that the timing of the economy's exit from a liquidity trap is endogenous. Moreover, at higher spending levels, the economy endogenously leaves the liquidity trap sooner. In turn, this decreases the size of the multiplier even when the economy is concurrently at the zero lower bound. Thus, there are diminishing and possibly negative returns to larger and larger spending programs.

Our findings suggest a different answer to their question: the expected inflation channel is quantitatively weak. Absent this mechanism, government spending is less likely to expand private economic activity.

Also, Erceg and Linde (2010) note that expected inflation, measured from the median value of the SPF, and actual inflation in the first two quarters following the passage of the Recovery Act moved quantitatively much less than implied by the calibrated sticky price model (their Figures 5a and $5 \mathrm{~b}$ ). We report this feature and also show that the pattern continues in the years following the Act's passage. We further show that the pattern is confirmed in a panel analysis of the professional forecasters, as well as in a cross-country comparison of nominal-indexed bond yield spreads.

Erceg and Linde (2012) explain how the size of the government spending multiplier, under a nonresponsive monetary policy, can be tied closely to the duration of price contracts. In one illustrative calibration (their Figure 3), they show how the output multiplier can be slightly greater than 1 under 10-quarter contracts and 25 under 10-quarter contracts. This is consistent with our analysis that a high output multiplier goes hand in hand with a large inflation response. ${ }^{32}$

In their calibrated medium-scale sticky price model (similar to that of Christiano, et.al. (2005)), Erceg and Linde (2012) find a muted response of inflation to a government spending shock - there is a roughly 20-basis-point inflation rate in the first year following an $\mathrm{AR}(1)$ spending shock with a cumulative value equal to $2.5 \%$ of one year of steady-state government spending (the dash-dotted line in their Figure 5). The corresponding impact multiplier is roughly 1 and their cumulative multiplier is approximately $0.5 .^{33}$

Next, Davig and Leeper (2011) study government spending shocks in a sticky price model under several different monetary/fiscal policy scenarios. They document how the expected inflation

\footnotetext{
${ }^{32}$ Denes and Eggertsson (2009) and Woodford (2011) show that a much larger intertemporal elasticity of substitution for consumption, relative to those commonly used, can result in both a large output multiplier and a moderate inflation response. A higher intertemporal elasticity can generate a large consumption response, even if the real interest rate decline is moderate as a result of a moderate increase in expected inflation. Their models are calibrated based on their analyses of the economic environment during the Great Depression rather than that for the post-WWII U.S.

${ }^{33}$ The multiplier increases somewhat when they add rule-of-thumb consumers and financial frictions.
} 
channel (although they do not use that term) operates when monetary policy is passive, and not simply at the zero lower bound. In contrast to Davig and Leeper (2011), our estimation of macro responses to spending shocks under passive policies using a structural vector-autoregression does not by itself depend on specifying a particular dynamic equilibrium model.

Next, whereas we find that the expected inflation channel was ineffective during the Recovery Act episode, Eggertsson (2012) states that the New Deal was very effective in reversing the initial contraction during the Great Depression. ${ }^{34}$ Following the line of reasoning offered in Eggertsson (2012), we offer a rationale for why the New Deal might have "worked" whereas the Recovery Act did not. First, the National Industrial Relations Act (NIRA) of 1933 gave goods market power to large corporations and labor market power to unions, which would have directly exerted upward pressure on markups and, therefore, inflation. In contrast, the Recovery Act expended a tremendous dollar amount; however, it did less to influence the degree of market power in the economy. Thus, the Recovery Act influenced prices more indirectly - through the government's increased demand for goods.

Several authors have noted that the channel is most effective when the government spending ends as soon as monetary policy is no longer passive. Eggertsson (2012) explains that the NIRA could be ended immediately either by the presidential proclamation or Congress. He interprets this to mean that the emergency measures would last as long as the shock.

With respect to the Recovery Act, reversing the measures once they were enacted was infeasible. In the first few months following the Act's passage, the federal government obligated hundreds of billions of dollars to state and local governments, nonprofit organizations and transfer recipients to be outlaid over the following several years. We contend that the federal government's attempt to renege on these commitments (supposing a fast economic recovery followed the Act's passage) would have created a political firestorm, and thus was unfeasible.

Our work is also related to several other papers on the expected inflation channel. First, Cochrane (2013) suggest an alternative to the rational expectations equilibrium concept entitled the "local-to-frictionless" equilibrium that undoes the large multiplier effect and several paradoxes in this line of research. His paper provides one potential explanation for why we find a small expected inflation effect in the post-WWII U.S. Second, Wieland (2013) shows that theoretically, at the zero-lower bound, negative supply shocks can be expansionary; he then provides evidence (from oil supply disruptions and earthquakes) that is inconsistent with this phenomenon. Third, Drautzburg and Uhlig (2013) quantify the fiscal multipliers following passage of the Recovery Act using a medium-scale New Keynesian model. Although their estimate accounts for the zero-lower bound, and thus the expected inflation channel, they find that multipliers are negative in the long-

\footnotetext{
${ }^{34}$ Denes, Eggertsson and Gilbukh (2013), using Bayesian methods, estimate that the multiplier during and following the 2007-2009 recession was lower (Bayesian posterior $=1.2$ ) relative to the Great Depression $($ Bayesian posterior $=$ 2.2). Their finding of a relatively smaller number is somewhat consistent with our results, except that their 2007-2009 multiplier remains greater than one. Differences between that paper and ours may arise because those authors chose random rather than deterministic duration fiscal/monetary policies.
} 
run and positive but less than one in the short-run. Fourth, Bachmann, Berg and Sims (2013) examine household-level survey data to assess whether higher inflation expectations lead to greater readiness to make a durable good purchase. They find that higher expected inflation reduces a household's self-reported likelihood of making the purchase.

\section{Conclusion}

We conclude by addressing economists' state of understanding about the Recovery Act's shortterm economic impact. Researchers have explored two distinct classes of mechanisms by which the Act, and government stimulus spending more generally, can influence economic activity: through a traditional mechanism and/or spillovers.

First, the traditional mechanism is that spending increases output and employment in the area where that stimulus money is spent. According to the traditional Keynesian logic, government purchases of furnish wages to workers, who in turn purchase goods that further stimulate output and employment nearby. This traditional mechanism has been estimated using cross-state variation in Recovery Act spending and economic outcomes. The preponderance of evidence from these studies is either that there is no statistically significant effect of spending on employment or that employment increases but at a very high price tag. ${ }^{35}$

The second class of mechanisms works through spillovers - output or employment goes up because of spending, but not because spending occurs nearby. The key difference between the spillover mechanisms from the traditional mechanism is that the effect on economic activity can be unrelated to the corresponding nearby spending.

The expected inflation channel is one such spillover mechanism that has been hypothesized. Why is this channel a spillover mechanism? Greater government spending in Iowa has an effect nationwide on expected inflation. This in itself will tend to increase consumption in Georgia through a fall in the real interest rate, even if Georgia were to receive no stimulus dollars at all.

This paper has provided evidence that this particular channel was quantitatively small or else nonexistent during the Recovery Act episode; other types of spillover mechanisms may have been more significant.

Consider taxes as one example. If Recovery Act spending signaled higher future tax rates, especially on capital, then this could have reduced economic activity upon news/passage of the Act. Exploring the magnitude by which higher expected future taxes rates might have reduced private activity during the Recovery Act episode merits future research.

Next, interstate or interregional movements in goods or factors of production provide other sources of spillovers. A negative spillover might occur if government spending in one state creates job openings that draw workers from other states. A positive spillover might occur if government

\footnotetext{
${ }^{35}$ See, for example, Conley and Dupor (2013), Dupor (2013), Feyrer and Sacerdote (2012) and Wilson (2011). A closely related paper is Dupor (2014).
} 
spending in one state provides income to citizens of that state, who in turn buy goods from other states.

\section{References}

American Recovery and Reinvestment Act, Public Law 111-5, 111th Congress, 17 Feb 2009.

Auerbach, A. and Y. Gorodnichenko (2012), "Measuring the Output Response to Fiscal Policy," American Economic Journal: Economic Policy 4, 1-17. n

Bachmann, R., T. Berg and E. Sims (2013), "Inflation Expectations and Readiness to Spend: Cross-Sectional Evidence," NBER Working Paper.

Bernstein, J. and C. Romer (2009), "The Job Impact of the American Recovery and Reinvestment Plan," Office of the Vice President-elect, working paper.

Blinder, A. and M. Zandi (2010), "How the Great Recession Was Brought to an End."

Boivin, J. and M. Giannoni (2006), "Has Monetary Policy Become More Effective?" Review of Economics and Statistics 88, 445-462.

Carlstrom, C., T. Fuerst and M. Paustian (2012), "Fiscal Multipliers Under an Interest Rate Peg of Deterministic vs. Stochastic Duration," Federal Reserve Bank of Cleveland, working paper.

Christiano, L. (2004), "The Zero-Bound, Zero-Inflation Targeting and Output Collapse," Northwestern University, manuscript.

Christiano, L., M. Eichenbaum and C. Evans (2005), "Nominal Rigidities and the Dynamic Effects of a Shock to Monetary Policy," Journal of Political Economy 113, 1-45.

Christiano, L., M. Eichenbaum and S. Rebelo (2011), "When Is the Government Spending Multiplier Large?" Journal of Political Economy 78-121.

Clarida, R., J. and M. Gertler (2000), "Monetary Policy Rules and Macroeconomic Stability: Evidence and Some Theory," Quarterly Journal of Economics.

Cochrane, J. (2013), "The New-Keynesian Liquidity Trap," University of Chicago, working paper.

Conley, T. and B. Dupor (2013), "The American Recovery and Reinvestment Act: Solely a Government Jobs Program?" Journal of Monetary Economics, forthcoming.

Council of Economic Advisers (various quarterly reports), "The Economic Impact of the American Recovery and Reinvestment Act of 2009." 
Davig, T. and E. Leeper (2011), "Monetary-Fiscal Policy Interactions and Fiscal Stimulus," European Economic Review 55, 211-227.

Denes, M. and G. Eggertsson (2009), "A Bayseian Approach to Estimating Tax and Spending Multipliers" Federal Reserve Bank of New York, working paper.

Denes, M., G. Eggertsson and S. Gilbukh (2013), "Deficits, Public Debt Dynamics and Spending Multipliers" Federal Reserve Bank of New York, working paper.

Drautzburg T., and H. Uhlig (2013), "Fiscal Stimulus and Distortionary Taxes" Federal Reserve Bank of Philadelphia, working paper.

Dupor, B. (2013), "Creating Jobs via the 2009 Recovery Act: State Medicaid Grants Compared to Broadly-Directed Spending," The Federal Reserve Bank of St. Louis.

Dupor, B. (2014), "The 2009 Recovery Act: Directly Created and Saved Jobs Were Predominantly in Government," Federal Reseve Bank of St. Louis Review, forthcoming.

Eggertsson, G. (2004), "Monetary and Fiscal Coordination in a Liquidity Trap," Chap. 3 of "Optimal Monetary and Fiscal Policy in the Liquidity Trap," PhD diss., Princeton Univ.

Eggertsson, G. (2012), "Was the New Deal Contractionary?" American Economic Review 102, 524-555.

Erceg, C. and J. Linde (2010) "Is There a Fiscal Free Lunch in a Liquidity Trap?" Board of Governors of the Federal Reserve System, working paper.

Erceg, C. and J. Linde (2012), "Is There a Fiscal Free Lunch in a Liquidity Trap?" Board of Governors of the Federal Reserve System, working paper.

Federal Reserve Bank of Philadelphia (2012), "Survey of Professional Forecasters: Documentation," updated August 10.

Feyrer, J. and B. Sacerdote (2012), "Did the Stimulus Stimulate? Effects of the American Recovery and Reinvestment Act," Dartmoth College, working paper.

Fisher, J. and R. Peters (2010), "Using Stock Returns to Identify Government Spending Shocks," Economic Journal 120, 414-36.

Mountford, A. and H. Uhlig (2009), "What Are the Effects of Fiscal Policy Shocks?" Journal of Applied Economics 24, 960-92.

Neely, C. (2010), "The Effects of Large-Scale Asset Purchases on TIPS Inflation Expectations," Federal Reserve Bank of St. Louis National Economic Trends, September. 
Ramey, V. (2011), "Identifying Government Spending Shocks: It's All in the Timing," Quarterly Journal of Economics 126, 1-50.

Ramey, V. and M. Shapiro (1998), "Costly Capital Reallocatoin and the Effects of Government Spending," Carnegie-Rochester Conference Series on Public Policy, June

Summers, L. (2008), "Update on Economic Policy Work," memo to President-Elect Obama, December 15 .

Taylor, J. (1999), "A Historical Analysis of Monetary Policy Rules," in Monetary Policy Rules, University of Chicago Press.

Taylor, J. (2007), Getting Off Track, Hoover Press.

Uhlig, H. (2005), "What Are the Effects of Monetary Policy on Output? Results from an Agnostic Identification Procedure," Journal of Monetary Economics 52, 381-419.

Wieland, J. (2013), "Are Negative Supply Shocks Expansionary at the Zero Lower Bound," University of California-Berkeley, working paper.

Wilson, D. (2011), "Fiscal Spending Multipliers: Evidence from the 2009 American Recovery and Reinvestment Act," Federal Reserve Bank of San Fransico, working paper.

Woodford, M. (2011), "Simple Analytics of the Government Spending Multiplier," American Economic Association Journal: Macroeconomics 3, 1-35. 